\title{
"Op die aarde net soos in die hemel": Matteus se eskatologie as die koninkryk van die hemel wat reeds begin kom het
}

\author{
Andries van Aarde ${ }^{1}$ \\ Fakulteit Teologie \\ Universiteit van Pretoria
}

\begin{abstract}
"On earth as it is in heaven": Matthew's eschatology as the kingdom of heaven that has come

In the article time as both "imagined" and "experienced" is explained against the background of the first-century Mediterranean conceptualisation of time. This reading scenario is seen as over against a modern Eurocentric ethnocentric interpretation of the concept "apocalyptic-eschatology". The aim of the article is to argue that Matthew's narration of the demolition of the temple in Jerusalem concurs with his belief that the first followers of Jesus experienced the vision of the coming of the Son of man and that both these experiences are presented in Matthew as though Jesus' crucifixion and resurrection are incidents of the past. Matthew's eschatology centres on the view that the final consummation of time has already begun. The article explores the ethical appeal which is communicated through such an eschatological reading scenario. This appeal is summarised by Jesus' words 'On earth as it is in heaven". The article consists of a conversation about core issues in mainstream interpretations of what Matthew's eschatology could be within the narrative's plot as it contextualised in formative Christianity and formative Judaism. The view assumed in this article is that the "time" and the experiences of Matthew's church and those of Jesus and his disciples are considered to be integrated within the history of Israel.
\end{abstract}

\section{INLEIDING}

Binne die vaktaal van Bybelse teologie is die begrippe eskatologie en apokaliptiek nou verweef. Albei hierdie uitdrukkings dui op die groot gewig wat

\footnotetext{
${ }^{1}$ Dr Andries G van Aarde is honorêre professor verbonde aan die Fakulteit Teologie, Universiteit van Pretoria, Suid-Afrika. Die artikel is 'n verwerking in Afrikaans van die Engelse referaat aangebied by 'n kongres oor die Eskatologie van die Nuwe Testament as boekprojek van De Gruyter Verlag (Berlyn, Duitsland), onder redaksie van proff Jörg Frey en Jan van der Watt, 20-23 Augustus 2007.
} 
op die begrip tyd gelê word. ${ }^{2}$ Die semantiese onderskeid tussen Israelse georiënteerde skrywers van Bybelse boeke en Grieks-Romeinse skrywers ten opsigte van terme wat tyd as konnotasie het, het in die verlede belangrike implikasies vir eksegese en teologie gehad. Die invloed van hierdie sosioreligieuse betekenis en antropologiese gebruik is egter deur Martin Hengel (1974) se insigte verander. ${ }^{3}$ Daar word vandag nie meer 'n skerp konseptuele onderskeid tussen Hellenistiese en Palestynse-Judaïstiese begripsmateriaal getref nie.

Ook is daar veral op grond van Martin Hengel se boek, Judentum und Hellenismus, begin om afstand te doen van 'n neiging tot 'n oorveralgemening van die tydsbegrip in die antieke tyd (Hengel [1969] 1974). So 'n vereenvoudiging het ons byvoorbeeld in Oscar Cullmann ([1946] 1971) se werk Christ and time: The primitive Christian conception of time and history. Hy meen naamlik dat ons moet uitgaan van die fundamentele siening dat die simbool van tyd vir die vroeë Christendom sowel as vir Bybelse Judaïsme en die Iranse religie 'n lyn is, terwyl dit in die Hellenisme 'n sirkel is (Cullmann 1971:5). Die implikasie van Cullmann se siening is dat enige moontlikheid van 'n sogenaamde "tussentyd" - 'n proleptiese redding of "gerealiseerde eskatologie" - in die denke van Nuwe-Testamentiese skrywers ook verwerp behoort te word. Cullmann (1956:165 e v) het hierdie oorvereenvoudigde siening (vgl Nickelsburg [1972] 2006:219-223) ook in 'n essay getiteld "The proleptic deliverance of the body according to the New Testament" verwoord.

\footnotetext{
${ }^{2}$ Vir 'n hedendaagse siening oor tyd in die antieke tyd, soos dit in die Nuwe Testament uitgebeeld word, kyk onder andere Kreuzer, Johann 2005a, Zeit- und Geschichtsbild, in Zangenberg, J (Hrsg), Neues Testament und Antike Kultur, Band 3: Weltauffassung - Kult Ethos, bl 110-114; Kreuzer, Johann 2005b, Von der erlebten zur gezählten Zeit: Die Anfänge der Zeitphilosophie in der Antike, in Kreuzer, J \& Mohr, G (Hrsg), Die Realität der Zeit, bl. 149; Jerome H Neyrey \& Eric Rowe [2008], "Telling time" in the Fourth Gospel (opgeneem in die onderhawige UP eeufeesviering HTS jubileumnommer); Bruce J Malina ([1989] 1996, Christ and time: Swiss or Mediterranean.
}

\footnotetext{
${ }^{3}$ Volgens Cullmann ([1946] 1971:50, 50 notas 1-3), byvoorbeeld, is alle filosofiese spekulasie in die Griekse filosofie aangaande die aard van tyd geheel en al vreemd aan die vroegste Christendom. Daarom meen hy dat ons die idee rakende die verloop van tyd wat in die Nuwe Testament veronderstel word, kan omskryf deur dit in teenstelling met die tipies Griekse idee te sien. Volgens die vroeëre oortuiging sou die Grieks-Romeinse tydsbegrip meer abstrak en staties en die Israels-Judaïstiese meer konkreet en dinamies wees (vgl Sterling 2000:792). Hierdie tipe onderskeid gaan van die aanname uit dat die stereotipering van tyd in die wesMediterreense (Grieks-Romeinse) gebied religieuse konnotasie het wat anders is as dié in die oos-Mediterreense (Semities-Nabye-Oosterse) gebied. Hierdie oortuiging word onder andere aangetref in werke soos Thorleif Boman (1954), Das hebraïsche Denken im Vergleich mit dem Griechischen en George Knight (1953), A Biblical approach to the doctrine of the Trinity. Soos James Barr (1961:8-20), vanuit die perspektief van die semantiek van die Hebreeuse taal, het Jannie Louw (1982:7-8) weer vanuit perspektief van die semantiek van die Griekse taal, skerp kritiek op onder andere Boman en Knight uitgespreek. Bruce Malina (1991:66-87), in sy sosiaal-wetenskaplike werk oor kulturele stereotipering, het weer die insig bevestig dat, wat die Mediterreense gebied betref, ons gemaklik in algemene terme van 'n "circumpersoonlikheid" kan praat.
} 
In hierdie bydrae het hy die uitspraak gemaak dat die algemene verwagting in die Nuwe Testament oor die opstanding uit die dood, dié is dat ons (d w s Christene se) liggame nie onmiddellik na die dood sal opstaan nie, maar eers by die eindtyd. Verder meen hy dat die Nuwe Testament nie die Griekse geloof in die onsterflikheid van die siel ${ }^{4}$ deel en ook nie siening bevat dat die gestorwenes voor die eindtyd reeds van die vrugte van die uiteindelike vervulling sal kan proe nie.

Navorsing vandag bevestig Cullmann se standpunt oor die eerste saak. ${ }^{5}$ Wat Cullmann se tweede saak betref, naamlik sy verwerping van "gerealiseerde eskatologie", is daar egter geen instemming by NuweTestamentici nie (vgl bv Dunn 2006:351). Inteendeel, George Nickelsburg (2007:223) verwys na Cullmann se standpunt as 'n "unitary Jewish view" en hy noem dit pure fiksie. ${ }^{6}$ Indien Cullmann, wat die tweede saak betref, reg sou wees, maak die volgende uitsprake in Matteus hoegenaamd geen sin nie: "Laat u koninkryk kom; laat u wil ook op die aarde geskied, net soos in die hemel" (Matt 6:10) en "Waarlik, Ek verseker julle: hulle wat my gevolg het, sal, wanneer die Seun van die mens op sy heerlike troon sit in die vernude wêreld ( $\dot{\nu} \nu T \hat{n} \pi \alpha \lambda ı \gamma \gamma \varepsilon \nu \varepsilon \sigma i \alpha)$, ook op twaalf trone sit en geregtigheid vir die twaalf stamme van Israel verkry (KمívovTEs)" (Matt 19:28) (eie vertaling).

Met die onderhawige artikel beoog ek om aan te toon dat die ooglopende bedoeling van hierdie uitsprake in Matteus ernstig opgeneem moet word, naamlik dat Matteus van oortuiging is dat die koninkryk van die hemel reeds begin het. Uitsprake soos dié in Matteus 6:10 en 19:28, asook

\footnotetext{
${ }^{4}$ Dit wil sê, hoewel die materiële liggaamlikheid van die mens by dood ontbind, leef die innerlike siel van die mens voort en is dus onsterflik. Hierdie antropologiese dualisme is 'n Griekse idee, terwyl daar in die Israelse opvatting nie 'n onderskeid tussen "liggaam" en "siel" getref is nie (kyk o a Nickelsburg 2006:234; Becker 2007:184-190).

${ }^{5}$ Vergelyk byvoorbeeld Tom Wright (2006:19) - in debat met John Dominic Crossan - wat die Nuwe Testament se "mutasie" van die Joodse opstandingsgeloof voorstel as 'n "single event taking place in two moments": eers het Christus opgestaan en daarna, by Christus se tweede koms (d w s by die "eindtyd", die paroesie), sal die Christene opstaan (vgl o a Wright 2003:31; Crossan [\& N T Wright] 2006:25-26; Nickelsburg [1972] 2006:227; Becker 2007:282). Insgelyks wat Nuwe-Testamentiese skrywers se alternatiewe "taal" ("opstanding en verhoging") teenoor die Platoniese idee van "onsterflikheid" betref, is daar in die Bybelwetenskap geen dispuut nie (kyk bv Dunn [1977] 2006:337-371). ${ }^{6}$ Vergelyk ook Kraft \& Nickelsburg (1986, veral die hoofstuk getitel "Diversity in postbiblical
Judaism”, bls 57-80).

${ }^{7}$ Hierdie vertaling word gegrond op Horsley (1987:201-207) se interpretasie en vertaling. Volgens Horsley (1991:196) sal diegene wat Jesus gevolg het, of met Hom volhard het, regverdigheid verkry vir die twaalf stamme van Israel op 'n manier wat baie soortgelyk is aan dié wat toegeken is aan die "Gesalfde" in die Psalms van Salomo 17:26-32; of aan die twaalf mans en drie priesters wat vir die Qumranse Gemeenskapsrol verantwoordelik was (kyk 1 QS 8:1-4).
} 


\section{"Op die aarde net soos in die hemel"}

makarismes soos dié dat die koninkryk van die hemel hier en nou ${ }^{8}$ aan die "armes van gees" behoort (Matt 5:3) en aan hulle wat hier en nou vervolg word, omdat hulle doen wat reg is (Matt 5:10), bevestig nie Cullmann se anakronistiese standpunt nie. Luise Schotroff (2006:84-85) verwerp daarom die Westers-georiënteerde "dualistiese eskatologie" wat Jesus se uitsprake oor die koninkryk van God "lynvormig" verstaan asof die etiese konsekwensies van hierdie uitsprake op 'n ander-tydse wêreld as hierdie wêreldse betrekking sou hê. Tog wil Schotroff ook nie Jesus of die vroegste Jesus-volgelinge as vreemd aan hulle eie tyd sien nie. Sy is daarom krities jeens die tendens om die "apokaliptiese oriëntasie" met 'n "akademiese, niedualistiese alternatief" (soos die sogenaamde "kerugmatiese oriëntasie") ${ }^{9}$ te vervang. Hoewel iemand soos James Robinson (2007:164 e v) ook bedenkinge teen hierdie in-die-lug-hangende "akademiese" denke het, hou hy ook nie van 'n moderne emansipatoriese "etiese idealisme" nie. Robinson (2007:164 nota 6) is daarom ongemaklik met Schotroff se beweerde "politieke korrekte" Jesus.

Die baba moet egter nie saam met die badwater uitgegooi word nie. Vanuit die perspektief van die hermeneutiek van suspisie oordeel ek dat Luise Schotroff se bydrae nie onderwaardeer behoort te word nie. Haar probleem met "akademici" en "kerkmense" se "nie-dualistiese alternatief" lê op 'n ander vlak as bloot die ideaal van om polities korrek te wees en om die propagering van bevrydingsteologies-etiese ideale. Volgens Schotroff is die hedendaagse siening dat Jesus nie-apokalipties sou wees, ${ }^{10}$ teensprekend omdat dit die

\footnotetext{
${ }^{8}$ Let spesifiek op die teenswoordige tyd in die werkwoord is ('ं०TIV) in beide die eerste en laaste makarismes in Matteus se reeks van agt (Matt 5:3-10).

${ }^{9}$ Hoewel ek met Schotroff se beklemtoning van "sosiale etiek" instemming het, is die negatiewe konnotasie wat sy heg aan die vermeende spanning tussen die sogenaamde "kerugmatiese oriëntasie" en die "apokalipties-eskatologiese oriëntasie" onnodig. In sy werk Kerygma, eschatology and social ethics lê Amos N Wilder (1966:31-32) 'n ander verband en hiermee het ek groter instemming: "Die skrywers van die Nuwe Testament in die algemeen, en Paulus in die besonder, bied as die spesifieke sentrum van hulle boodskap rakende sosiokulturele handelinge 'n teologiese basis, Sonder twyfel was die eerste Jesus-volgelinge by so 'n aksie betrokke toe hulle met hulle transformasie van die kultuur van die heidense beskawing besig was. Hulle was terdeë bewus dat hierdie aksie inherent deel van die evangelie is. Dit is ons wat nie daarin slaag om hulle erns daarmee raak te sien nie .... Die eskatologiese en dualistiese simboliek in die taalgebruik van Jesus se vroegste volgelinge kan ons verlei deur te dink dat die evangelie in daardie klassieke era geen belang by dít gehad het wat ons vandag sosiale verandering noem nie" (my vertaling en interpretasie). Dit is waarom ek waardering het vir Theissen se kritiek op daardie tipe eksistensiale interpretasie wat nie sosiale implikasies van die evangelie in ag neem nie.

${ }^{10}$ Byvoorbeeld, volgens Schotroff sou dit dié "standpunt" van die Jesus Seminar wees. Sy fouteer egter net soos baie ander akademici en nie-akademici om te veralgemeen, asof alle lede van die Jesus Seminar presies dieselfde oortuigings sou huldig. Vergelyk egter die oortuiging van Crossan (1997:33-35; 1998:273-292, 284-285), wat hieronder bespreek word, asook my eie wat nie met hierdie veralgemening ooreenkom nie (Van Aarde 2001a:30; 2001b:1158-1178).
} 
sosiale etiek van Jesus aan die een kant konkreet relevant vir mense wil maak, maar aan die ander kant die inhoud van sy koninkryksuitsprake as metaforiese spreke wil vergeestelik. ${ }^{11}$ Schotroff (2006:83-86) sê in geen onduidelike taal dat haar "sosio-historiese Bybelinterpretasie" ten doel het om onder andere Jesus se gelykenisse en sy eerste volgelinge se interpretasies daarvan - ingebed in Israelse en vroeg-Christelike apokalipties-eskatologiese denke - só te kontekstualiseer, dat dit betrekking kan hê op alle fasette van 'n "lewe van praxis".

Teen die agtergrond van my waardering vir so 'n "hermeneutiesbetrokke" Bybelinterpretasie, oordeel ek dat bogenoemde uitsprake in Matteus oor die realiteit van die koninkryk van God daarop dui dat "eskatologie" in Matteus na 'n herordening van waardes binne die ekklēsia verwys. Hierdie "herordening" noem ek 'n kosmiese transformasie. My oortuiging kan verduidelik word aan die hand van uitsprake deur John Dominic Crossan (in Stewart 2006:24-25) wanneer hy met nie-vakmense oor "eskatologie" en "apokaliptiek" kommunikeer: As julle geloof vir julle sê dat God regverdig is en dat die wêreld aan God behoort, en julle ervaring vertel julle op ontstellende wyse dat julle ' $n$ klein, gehawende volkie is, dan is eskatologie waarskynlik onvermydelik. Moenie dat ons as Bybelkenners julle hieroor verwar nie. Eskatologie beteken dat - as die wêreld aan God behoort en kennelik onregverdig is - dan moet God die gemors in die wêreld opruim. Eskatologie $^{12}$ is dus die "Groot Goddelike Opruiming" van die wêreld" (my parafrase).

\footnotetext{
${ }^{11}$ Ten spyte van my kritiese opmerking in die vorige voetnota oor Schotroff se veralgemenende uitspraak, lyk dit egter nie vir my of sy regstreeks die lede van die Jesus Seminar (vgl Stephen J Patterson 1992, in Westar Institute Program, 27 February-1 March 1992; Funk \& The Jesus Seminar 1999:92; kyk veral Robert J Miller (2001). The apocalyptic Jesus: $A$ debate) of 'n sogenaamde kontemporêre Noord-Amerikaanse tendens van "Jesusas-nie-eskatologies" (Borg 1994a, 1994b) in die oog het nie. Sy praat myns insiens meer vanuit haar ervaring van die sienings van kollegas in veral Duitsland. 'n Soortgelyke sensitiwiteit, ook vanuit die konteks van die Duitse Nuwe-Testamentiese Wetenskap, is by Gerd Theissen ([1974] 1983) te bespeur. Ook Theissen kritiseer die "kerugmatiese eksegese" (veral beoefen in die Barth- en Bultmann-skole deur dialektiese teoloë) omdat dit nie werklik die sosiale en menslike verhoudings in ag neem wat agter tekste soos byvoorbeeld die verhale oor wonderwerke in die Nuwe Testament verskuil lê nie. Hy vind dit problematies as ons te geredelik die realiteite van die angs vir siekte, honger en die dood uit die oog verloor deurdat ons sodanige tekste bloot kognitief benader en dus hulle sosiale alledaagse betekenis omskep in idees asof hierdie tekste in vakuum sonder raakpunte met die grondvlak van die samelewing ontstaan het. Theissen toon oortuigend dat wondervertellings in die antieke tyd (insluitende dié in die Bybel) gefunksioneer het te midde van sosiale konflik. Dit is tekste wat gedien het as die legitimering van sekere ideologiese belange.

${ }^{12}$ Volgens Crossan verwys "'n Apokalipsis dan na 'n spesiale Goddelike openbaring [aan 'n "siener" wat 'n nabye kontak met die transendentale beleef] dat hierdie eskatologie reeds voor die deur lê. Die openbaring kan gaan oor enigiets wat met hierdie opheffing van ongeregtigheid verband hou. Apokaliptiese eskatologie verwys dus daarna dat diegene wat onregverdig ly, daarop aanspraak kan maak dat hulle bewus is van een of ander spesiale openbaring oor hoe en wanneer God met die "Groot Goddelike Opruiming" gaan begin (my parafrase van en toevoeging tot Crossan).
} 
Hoewel ek van oortuiging is dat die "tydskategorieë" wat in die begrippe eskatologie en apokaliptiek ter sprake kom, in wese sosiale konstrukte is, meen ek ook dat ons in ag behoort te neem dat "tyd" in die bestudering van die evangelies toenemend betekenisvol geword vir eksegete wat van narratiewe kritiek as eksegetiese benadering gebruik maak. Tyd as 'n narratologiese begrip verwys na die manier waarop die ontleding van 'n vertelling se plot en intrige in eksegese aangewend word. Intrige en plot impliseer 'n narratief wat bestaan uit gebeure, geselekteer uit die lewens van mense in 'n sekere tyd en plek, wat 'n verteller op so 'n wyse kombineer dat dit 'n kousale struktuur daarstel. Om dit anders te stel: 'n narratief is 'n diskoers waarin taal gerangskik is in terme van karakters wat binne 'n gegewe struktuur van tyd en ruimte beweeg. In 'n narratief vervul karakters interaktiewe rolle in episodes wat tot kronologies opeenvolgende aksielyne ontwikkel. Elke reeks of opeenvolging bevat interaksies, dit wil sê aksies van karakters wat deur 'n kousale verhouding gerig word. Dit is hierdie kousaliteit van interaksies wat die intrige van 'n narratiewe diskoers daarstel.

'n Elementêre, goed-gestruktureerde intrige bestaan uit 'n lineêre opeenvolging met 'n begin, 'n middel en 'n einde. ${ }^{13}$ 'n Geslaagde einde beteken egter nie noodwendig 'n algehele opheffing van die spanningslyn nie. Die meeste goed-georganiseerde vertellings beskik oor oop eindes, met die gevolg dat die leser in die intrige ingetrek word en in die interaksies betrokke raak. Die intrige strek dus verder as die eintlike vertelling en het 'n eie lewe selfs nadat die woorde en sinne op die bladsy tot 'n einde gekom het (kyk Van Aarde 2006:670-672). So word die verhaal van die "kerk" in beide Markus en Matteus nie so vertel soos dit in Lukas-Handelinge voorgestel word nie. In 'n sekere sin is die Handelinge van die Apostels 'n eksplisering van hierdie verhaal van die "kerk". In Markus en Matteus word die verhaal van die "kerk" eerder geïmpliseer. Nadat Jesus oor sy opponente in Jerusalem geseëvier het ten spyte van sy dood, gaan die intrige verder as Matteus 28:16-20 se weergawe van Jesus se opstanding.

In die onderhawige artikel word die eskatologie en apokaliptiek in Matteus ondersoek deur middel van 'n oorweging van beide die narratologiese aspek van tyd sowel as tyd as 'n sosiale konstruk. Twee aannames waarop daar in hierdie artikel gesteun word, moet daarom reeds hier genoem word. Die een is dat apokaliptiek ondenkbaar is sonder geloof in

\footnotetext{
13 '"n Geheel,' sê hy [Aristoteles], 'is dit wat 'n begin, 'n middel en 'n einde het ... 'n Begin is dit wat nie self op grond van kousale noodsaaklikheid enigiets anders volg nie, maar waarop iets natuurlik volg of tot stand kom. 'n Einde, in teenstelling daarmee, is dit wat self natuurlik op 'n ander ding volg, hetsy uit noodsaaklikheid, hetsy as 'n reël, maar waarop niks volg nie. 'n Middel is dit wat op iets anders volg, en wat deur iets anders gevolg word" (eie vertaling van Aristoteles, Poetica vii.3, o g v teks in Butcher [1894] 1951:279-280).
} 
die opstanding vanuit die dood. ${ }^{14}$ Derhalwe is 'n kort kamee oor die oorvleueling tussen die begrippe eskatologie en apokaliptiek in orde, sonder om te veel op terminologie te konsentreer - veral omdat die oorsprong van Ernst Käsemann se bekende uitspraak dat apokaliptiek die moeder van alle Christelike teologie is, in die konteks van Matteusstudies gevind word. ${ }^{15}$ Volgens Käsemann ([1960] 1969:82-107) was dit die reaksie op die dood van Jesus deur die vroegste Jesusgroep in Jerusalem - en wat Matteus aan ons oorlewer - wat ons lei na die oorsprong van "Christelike teologie". ${ }^{16}$

Die tweede aanname is dat hierdie "reaksie" betrekking het op Christelike etiek, dit wil sê, die manier waarop ons Jesus se opdragte aan sy dissipels verstaan. 'n Mens sou kan beweer dat die intrige van al die kanonieke evangelies rondom die verband tussen Jesus se sending en die dissipels se sending ontwikkel en ontplooi. In Matteus word die lesers voor die uitdaging van Jesus se "groot opdrag" (in hoofstuk 28:16-20) gestel. Die lesers van Matteus word oor hierdie opdrag aan die dissipels aan die einde van die verhaal ingelig en word self met die opdrag gekonfronteer deurdat hulle en spesifiek hulle eie tyd eksplisiet in hierdie finale episode ingetrek word. Die God-met-ons-uitspraak word in hierdie episode gekontekstualiseer deur die effek van die uitspraak te laat geld gedurende nie net in die tyd van die dissipels nie, maar ook in die tyd van die lesers van Matteus - sowel as in die tyd van ons as vandag se lesers, want die effek van die uitspraak geld tot die "voltooiing van hierdie-wêreldse tyd". Die opdrag aan die dissipels in hierdie "finale episode" word dus ook 'n vraag waarop die lesers moet antwoord: sal hulle, die lesers, soos die dissipels wees wat hulle sendingroeping van die opgestane Jesus in Galilea ontvang het om dissipels

\footnotetext{
${ }^{14}$ Volgens Crossan (in Stewart 2006:25) hou "apokaliptiese eskatologie" so sterk verband met die opstandingsgeloof dat ' $n$ mens baie stellig kan sê dat "opstanding uit die dood" die agtergrond, voorgrond en matriks van apokaliptiese eskatologie vorm. Daarsonder, volgens Crossan, praat ons nie eens oor dieselfde ding nie!

${ }^{15}$ Volgens Schmithals (1994:20; vgl 1973:129; 1975:72), kan daar met Käsemann saamgestem word as die onderlinge verhouding tussen apokaliptiek en die Christendom histories verstaan word. Saaklik gesien, wil Schmithals, soos die Bultmann-skool, egter nie die Christendom sien as 'n positiewe produk van apokaliptiek nie, maar eerder dat dit die negatiewe elemente van die apokaliptiese idee "oorwin" het.

${ }^{16}$ Met betrekking tot apokaliptiek toon Käsemann aan dat Matteus klein brokkies bevat wat nie in die ander evangelies voorkom nie, maar wat ons help om die oorspronge van die vroegste Christelike teologiese denke te rekonstrueer. Aan die hand van aanhalings uit die Hebreeuse Bybel (bv Matt 7:22-23; 23:8-10; 5:19) wys hy daarop dat daar agter hierdie brokstukke van tekste 'n geskiedenis skuil waarin daar duidelik 'n spanning te bespeur is wat spruit uit teologiese dispute oor die reaksie op Jesus se dood. Die histories-kritiese rekonstruksie van hierdie "reaksie" is volgens Käsemann (1969:82) moeilik, omdat slegs fragmente aangaande die eerste Jesusgroep in Handelinge beskikbaar is. Hierdie min inligting in al die klein stukkies vorm wel 'n soort mosaïek, maar dit bied te min om duidelike uitleg vas te stel oor wat presies die vroegste "teologie" behels het. Dat hierdie "teologie" apokalipties gekleur is, is egter wel duidelik.
} 
van alle mense te maak deur hulle te leer hoe om dit te vermag wat Jesus self gedoen het?

Die verteller in Matteus skep met ander woorde 'n verband tussen die lesers en die dissipels, net soos daar 'n verband tussen Jesus se sending en die dissipels se sending geskep is. Hierdie relasie tussen Jesus se opdrag en die dissipels se opdrag word op die mees kompakte manier saamgevat in Jesus se uitspraak in sy bede in die Onse Vader: op die aarde, net soos in die hemel (Matt 6:10c) - 'n gelade frase wat voorafgegaan word deur soortgelyke ryk aforismes: "laat u koninkryk kom" en "laat u wil geskied".

Die uitbeelding van die interaksie tussen Jesus en sy dissipels ontplooi in Matteus teen die historiese agtergrond van beide 'n bepaalde proses en van 'n bepaalde denkpatroon. Die proses was dié van die "skeiding tussen die sinagoge en die kerk" wat begin het na die vernietiging van die tempel in Jerusalem in $70 \mathrm{nC}$, maar met die skryf van Matteus nog nie afgehandel was nie (kyk Respschinski 2000:30-50). Die denkpatroon was dié van die apokaliptiek wat Matteus van Markus oorgeneem het (en van 'n latere weergawe van $\mathrm{Q}$ ). Net soos in die ander Sinoptiese Evangelies, gee Matteus sy begrip van die dood en opstanding van Jesus weer in die lig van hierdie apokaliptiese denke. ${ }^{17}$ Die apokalipties-eskatologiese verwagting was dat hierdie wêreld omskep sou word in die uiteindelike koninkryk van God.

In die onlangse verlede was daar 'n merkbare toename in die aantal publikasies oor die eskatologiese verwagtinge in die Matteusevangelie. ${ }^{18}$ Myns insiens kan aspekte van die eskatologie in Matteus verhelder word deur meer aandag te gee aan Käsemann se insigte en eksegese wat tot sy bekende uitspraak oor apokaliptiek as die moeder van alle Christelike teologie gelei het. Die rede vir my oortuiging is dat die agtergrond van Käsemann se

\footnotetext{
${ }^{17}$ Die plaasvervangende dood van 'n martelaar was ' $n$ belangrike dinamiek in hierdie verwagting, omdat die martelaar gesterf het in die plek van ander om 'n beter toekoms vir hulle na die dood te verseker (kyk o a Theissen 1999:150). Volgens hulle "skrifgeleerde" eksegese van die Hebreeuse Bybel het die vroegste Jesus-volgelinge in Jerusalem geargumenteer dat God se "imperiale heerskappy" ingelui is deur Jesus. Hulle het Jesus geeër as Israel se geesvervulde messias wat getriomfeer het deur sy oorwinning oor die dood. Hierdie oorwinning was in messiaanse kringe as 'n gebeure gesien wat toegeskryf is aan die Seun van die mens (kyk Matt 27:51e v). Hierdie "figuur" was daardie triomfantelike apokaliptiese persoon wat verwag is op daardie tydstip in die geskiedenis toe die wedervaringe in hierdie wêreld amper ondraagbaar was. Dié neerslagtige ervaring het gelowiges laat begin fantaseer oor die aanbreek van God se koninkryk wat die bekommernisvolle tye waarin die mense geleef het, tot 'n einde sal bring (kyk inter alia Dan 7:13-14).

${ }^{18}$ Kyk byvoorbeeld die werke van, onder andere, Donald Hagner $(1985,1994)$, David Sim (1996), Ferdinand Hahn (1988), O Lamar Cope (1989), David Orton (1989), Dale Allison (1982), Jane Schaberg (1982), Wim Weren (1979) en Herman Waetjen (1976).
} 
insigte bewustelik of onbewustelik baie idees in hedendaagse navorsing oor Matteus se eskatologie beïnvloed het.

Ongelukkig ontbreek die woorde "eskatologie" of "apokaliptiek" in die titels van baie resente werke en hierdie werke word dus maklik oor die hoof gesien. Nog 'n probleem is dat teoloë wat hulle met die eskatologie en/of apokaliptiek in die Matteusevangelie bemoei, met baie min uitsonderings, nie aandag skenk aan òf mekaar se werk òf hulle voorgangers se insigte nie (al is dit maar oorsigtelik). Hier dink ek nie slegs aan 'n verwysing hier en daar na die baanbrekerswerk van Günther Bornkamm (1956) ${ }^{19}$ nie, maar ook aan die werke van 'n vorige generasie navorsers. ${ }^{20}$

Hierdie artikel bestaan daarom uit die volgende onderafdelings: (1) 'n beoordeling van die stelling dat apokaliptiek die "moeder is van alle Christelike teologie" soos dit in Matteus ontplooi word; ${ }^{21}$ (2) 'n kort bespreking van die begrippe eskatologie en apokaliptiek; (3) 'n oorsig oor die onderskeie opeenvolgende narratiewe handelingslyne in Matteus; (4) 'n ondersoek na die eskatologie in Matteus as integrale deel van Matteus se verhaal en sy intertekste.

\section{2. "DIE MOEDER VAN ALLE CHRISTELIKE TEOLOGIE"}

In die tydperk toe die Nuwe Testament geskryf is, het verskillende idees oor hoe die wêreld begin het en hoe, onder watter omstandighede en wanneer dit weer sal vergaan, die rondte gedoen. Breedweg kan die opvatting oor die eindtyd as "eskatologie" beskryf word. Meer as een siening oor die aard van hierdie "eskatologie" het gedurende die periode direk voor en na die ontstaan van die Nuwe Testament voorgekom. Apokaliptiek as wêreld- en

\footnotetext{
${ }^{19}$ Bornkamm het daarop gewys dat daar ' $n$ vervlegting (Verklammerung) van ekklesiologie en eskatologie in Matteus is. Hy meen dat die sogenaamde uitgebreide "toesprake" van die Jesus wat ons uit Matteus ken, getuig van Matteus se teologiese siening van die verhouding tussen ekklesiologie en eskatologie. Hoofstuk 13, bestaande uit sy sewe gelykenisse oor die hemelse koninkryk, verkondig die idee dat Matteus se gemeenskap nie slegs 'n versameling van die uitverkorenes en die regverdiges is nie, maar 'n corpus mixtum wat die laaste oordeel tegemoetgaan. By die paroesie sal die kaf van die koring geskei word.

${ }^{20}$ Kyk byvoorbeeld Strecker (1966), Walker (1967), Trilling (1969a, 1969b), Kingsbury (1973), Meier (1975) en Senior (1976). Ook in hierdie geval word daardie werke wat in hulle titels nie ooglopend na begrippe soos "eskatologie', "apokaliptiek" of "paroesie" verwys nie, maklik deur navorsers verontagsaam.

${ }^{21}$ Hierdie artikel ondersoek ook nie 'n ander kwessie in resente Jesus-studies nie, naamlik of Jesus 'n eskatologiese figuur was al dan nie (kyk o a The apocalyptic Jesus: A debate, onder redaksie van Robert J Miller 2001).
} 
lewensbeskouing ${ }^{22}$ kan as een van die verskeidenheid "eskatologieë" in die oos-Mediterreense wêreld van die eerste eeu beskou word. Jesus se begrip van die "koninkryk van God" - oftewel in Matteus se terme, die "koninkryk van die hemel" - was ingebed in die konteks van "etiese eskatologie" (wat ook soms sosiale apokaliptiek genoem word). ${ }^{23}$ Bruce Malina (2001:35) sê in geen onduidelike taal nie dat "Jesus' proclamation of the kingdom of God was, indeed, his social gospel." Jesus het sy boodskap van die koninkryk van God oorgedra in die vorm van gelykenisse en genesings - deur dit wat hy gesê en gedoen het, deur sy woorde en dade .

Volgens Käsemann het strydende partye onder die vroegste volgelinge van Jesus aan die een kant aanspraak gemaak op die gawes van God se Gees, terwyl hulle aan die ander kant mekaar aan die hand van "kriteria van die Gees" veroordeel het. Die verwysing in Matteus 7:22-23 (die einde van die Bergrede) na "vals profete" is 'n sodanige polemiese uitspraak (vgl ook Carter 2000:191; Garland [1993] 1995:89). ${ }^{24}$ Matteus was volgens Käsemann (in

\footnotetext{
${ }^{22}$ Anders as in Engels, waar die term "apocalypticism" te onderskei is van die term "apocalyps(es)", terwyl die term "apocalyptic" as byvoeglike naamwoord saam met uitdrukkings soos "apocalyptic language", "apocalyptic myth", "apocalyptic genre" en "apocalyptic eschatology" gebruik word (kyk Collins [1984] 1998:1-42, is die woord "apokaliptiek" vir Afrikaanse gebruikers meer omvattend, en daarom ook meer verwarrend. In hierdie artikel word die uitdrukking "apokalipties" gebruik as 'n byvoeglike naamwoord en "apokaliptiek" as 'n selfstandige naamwoord wat verwys na die wêreldsiening van apokaliptiese groepe wat soms 'n literêre dokument geskep het wat 'n "apokalips" (bedoelende 'n genre) genoem word en waarin mindere of meerdere aspekte van "apokalitiese taal" kan voorkom (kyk Murphy 1994:160-161). Die uitdrukking "apokaliptiese eskatologie" word in die artikel spesifiek gebruik as een voorbeeld van verskillende soorte "eskatologieë".
}

${ }^{23}$ Asketisisme is nog 'n vorm (Crossan 1998:265-271, 283-284). Selfs gebed veronderstel dat hierdie wêreld tot ' $n$ einde gekom het en vervang is deur God se wêreld waarin kommunikasie tussen God en die mens plaasvind, al is dit slegs vir 'n kort rukkie. Alle "eskatologieë" ("asketisisme" of "apokaliptiek") bepleit die gedagte dat God se volmaakte wêreld volbring sal word deur die beëindiging van die geskape wêreld wat deur sistemiese boosheid oorgeneem is. 'n Apokaliptiese perspektief op die einde van die wêreld bestaan uit 'n kosmiese ramp en katastrofe wat uitgedruk word in simboliese taal wat verwys na aardbewings, gevalle sterre, donkerte in daglig, leë grafte, heilige oorloë, ensovoorts. Asketisisme, aan die ander kant, bring ook die wêreld tot 'n einde, byvoorbeeld, deur selibaatskap. Nog 'n vorm van "eskatologie" is "etiese eskatologie" of "sosiale apokaliptiek" (Crossan 1998:284-285).

${ }^{24}$ Volgens Käsemann is hierdie polemiek nie op die Fariseërs gemik nie, maar op volgelinge van Jesus met 'n "geesvervulde vroomheid" wat daarop aanspraak maak dat slegs hulle die gawe en outoriteit het om wonderwerke te verrig, soos profesie, die uitdrywing van bose geeste en geloofsgenesing. Volgens Hare (1993:86) weerspieël Matteus 7:21-23 'n onderskeid tussen invloedryke Jesus-volgelinge (moontlik leiers van die Christelike geloofsgemeenskap) en Jesus-volgelinge onder die meer eenvoudige mense, dit wil sê die "volk van die land". Die parallelle passasies in Lukas 6:46 en 13:26 v bevat nie hierdie konkrete voorbeelde nie. Volgens hom lyk dit dus asof Matteus (ons vind ook 'n verwysing hierna in Handelinge) se uitsprake betrekking het op 'n "entoesiastiese" groep onder Jesusvolgelinge in Palestina wat afkomstig is uit die nie-Israelse, Grieks-Romeinse gemeenskappe. Hare is van oordeel dat Matteus homself van hierdie Jesus-groep gedistansieer het. Tog verwys Matteus nie na sy "opponente" se "dwalinge" nie en hy kritiseer hulle ook nie. Carter (2000:141]) het 'n soortgelyke opinie ten opsigte van die verwysings in Matteus 5:20. 
ooreenstemming met Schlatter 1933), waarskynlik 'n "etiese rigoris"25 en 'n verteenwoordiger van die vroegste "Christelike rabbinaat". Matteus se kritiek kon slegs kom van mense wat hulleself gesien het as persone wat die gawe van die Gees ontvang het en met hulle Tora-onderrig outoritêr in die gemeenskap wou wees op grond van die "gesag van die Gees van God" (Käsemann 1969:85). Hoofstuk 10:5 v is 'n ander voorbeeld ${ }^{26}$ waar ons Matteus se mening in hierdie verband hoor. Matteus 5:17-20 is nog 'n baie spesifieke voorbeeld van hierdie polemiek. ${ }^{27}$ Volgens Käsemann het die twee strydende groepe dus verskillend gedink oor die "einde van dae". ${ }^{28}$ Dit is teen hierdie agtergrond dat Käsemann (1969:89) sy begrip van die oorsprong van

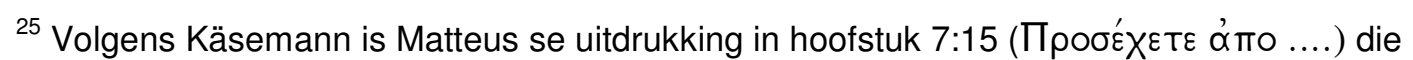
oordeelsformule aan opponente gerig en dit kom uit Psalm 6:9 ("Gaan weg van my ....) wat dieselfde implikasie as dié in Matteus 7:22-23 het, naamlik "Ek het jou nie geken nie." Hier gebruik Matteus die regsterm ó
}

${ }^{26}$ Matteus 10:5 v kom nie in die ander Sinoptiese Evangelies voor nie. Hier vind ons die strengste vorm van "Joodse Christendom", wat nie enige vorm van sending buite die grense van Israel voorstaan nie, selfs al was sendingwerk onder die heidene reeds aan die gang. (Handelinge het soortgelyke verwysings.) Matteus se afkeer aan die sending onder die heidene en Samaritane moet volgens Käsemann vanuit 'n apokaliptiese perspektief verstaan word wat alreeds in die Ou Testament aanwesig is (bv Sag 2:11; vgl. ook Targum van Jes 2:2b; 2 Esra 13:49; 2 Bar 72:3-6). Volgens hierdie idee van die nasies se pelgrimstog na die Sionsberg sal God Israel en die nasies dáár bymekaarmaak om God dáár te prys. God sal die "verlore skape" versamel en God sal vir die heidene sorg dra. Mense moet hulleself dus nie hierdie eer toeëien wat God toekom, en self met 'n sending na die heidene begin nie. Al wat Matteus van Jesus se volgelinge verwag, is dat hulle die "verlore skape van Israel" sal bymekaarmaak sodat die paroesie van God kan aanbreek. Käsemann (1969:88) sien hierdie verwagting as min of meer soortgelyk aan Paulus se boodskap in Romeine 11:25 v. Die gevolg is, volgens Käsemann (1969:88), dat al wat mens nou kan doen, is om die "verlore skape van die huis van Israel" terug te lei, sodat digene wat deel van die "twaalf stamme" is, in 'n eenheid saamgesnoer word tydens die aanbreek van die Messias se paroesie.

Hierteenoord het die ander strydende groep egter gemeen dat die einde van die wêreld reeds met die Paasgebeure en die vervulling van die Heilige Gees 'n werklikheid geword het. Volgens hierdie groep is die sending na die heidene een van die eskatologiese tekens wat God inlei en nie deur mense bewerk word nie.

\footnotetext{
${ }^{27}$ Matteus 5:17-20 is 'n baie spesifieke voorbeeld van die polemiek aangaande die volgehoue geldigheid van die Tora. Matteus handhaaf hierdie volgehoue eis van die Tora tot die laaste jota en tittel. Die vorm van Matteus 5:19 is daarom belangrik, omdat dit die apokaliptieseskatologiese vorm van die "heilige wet" - die jus/lex talionis vertoon (kyk ook Käsemann 1954-55:124-147 Käsemann (1969:87) meen dat daar vir die eerste keer in die geskiedenis van die kerk 'n situasie ontstaan het waarin die "Gees" teenoor die "Gees" te staan gekom het - of om dit anders te stel: "Tora teen Tora".

${ }^{28}$ Die een groep was gebind aan die verwagtings rondom Israel se nasionale hoop, terwyl die ander hierdie eskatologiese tradisie nie as so dringend gereken het nie. Albei groepe het gemeen dat die paroesie spoedig sou aanbreek (kyk Mark 9:1 en Matt 16:28; 24:34). Hulle het geglo dat dit selfs in hulle eie tyd sou plaasvind. Volgens Käsemann was dit nie die vervulling deur die Gees as sulks wat gelei het tot die dispuut tussen die twee groepe nie, maar die verskillende "teologieë" wat die twee groepe gehuldig het.
} 


\section{"Op die aarde net soos in die hemel"}

Christelike teologie rekonstrueer. ${ }^{29}$ Die uiteinde van die Matteaanse gemeenskap was dat hulle as 'n sekte gemarginaliseer is. ${ }^{30}$ Te midde van die steeds groeiende sending onder die heidene was hulle sendingwerk op die "verlore skape van Israel" gerig.

Dit is dan teen hierdie agtergrond dat Wim Weren (1979) in sy dissertasie oor Matteus se eskatologie na Matteus se de-apokaliptiserende neiging (Entgeschichtlichung der Eschatolologie) ${ }^{31}$ verwys. Volgens hom hef Matteus die apokaliptiek se tipiese dualisme tussen 'n huidige wanhopige tyd en 'n imminente tyd van redding op en herfokus hy die aandag op die etiek van omgee vir en versorging van die armstes onder die armes (die oi ¿̇ $\propto$ Xí⿴囗十丁 - Matt 25:45). Weren verwys na hulle in die titel van sy boek as "die broers van die Seun van die mens" ("de broeders van de Mensenzoon"). Volgens my is dit hierdie groep wat in Matteus die objek van beide die Jesussending en die dissipels-sending gevorm het (Van Aarde 2007:420-422; vgl Weren 1979:188). ${ }^{32}$

Weren (1979:190) se bevinding is dat die eschaton in Matteus funksioneer as 'n kontinue teenwoordige perspektief deur middel waarvan die lesers opgeroep word om nie vrede te maak met hulle onmiddellike konkrete omstandighede nie, maar om dit eerder deur dade te oorwin. 'n Eskatologiese uitspraak is daarom soos 'n etiese versoek. ${ }^{33}$ 'n Eksplisiete voorbeeld is dié in die Onse Vader-gebed, te wete die bede dat God se koninkryk moet kom, gevolg deur die uitspraak "op die aarde net soos in die hemel" (Weren

\footnotetext{
${ }^{29}$ Volgens Käsemann is die "Helleniste" (kyk Hand 6 - vgl Riches 1997:46-47) uit Jerusalem verdryf, en in Antiogië het hulle die voorgangers van die latere Pauliniese apostolaat geword. Jerusalem was die streng Judaïsties-Christelike groep se sosiale lokaliteit. Die lede van hierdie Jesus-groep het hulleself toenemend in 'n steeds groeiende Christendom met wortels ondere die heidene bevind.
}
${ }^{30}$ Vir resente besprekings van "sektarianisme" in Matteus, kyk Luz ([1985] 1989:219); Overman (1990:154); Saldarini (1991:44-60); 1994:84-123); Duling (1995a:159-182; 1995b:1-30); Sim (1996:182-192; 1998:113); Riches (1997:76-78); Carter (2000:43-49).

${ }^{31}$ Weren $(1979: 188$ nota 16, 236) verwys na onder andere die werk van A Sand (1972-3), Zur Frage nach dem "Sitz in Leben" der apokalyptischen Texte des Neuen Testaments. NTS 18, 167-177.

${ }^{32}$ In my artikel "Jesus' mission to all of Israel emplotted in Matthew's story" (Van Aarde 2007) het ek geredeneer dat, alhoewel die "skare" en die heidene nie dieselfde karakterrolle in die plot van Matteus speel nie, albei groepe saam as die objek van die sending van sowel Jesus as die dissipels in die tyd na die Pase funksioneer. Hierdie siening staan dus die mening teë dat daar 'n na-Pase diskontinuïteit tussen die "Israelitiese skare" as die objek van die Jesussending en die heidene as die objek van die dissipels-sending bestaan. Die "sending" wat in sowel Matteus 10 as Matteus 28:16-20 vermeld word, verwys myns insiens na die sending van Jesus se twaalf dissipels na die "verlore skape van Israel" (Van Aarde 2007b:419).

33 “... in de redactie van Mattheüs kan worden aangemerkt, dat hij eschatologische uitspraken verbind met concrete appèls" (Weren 1979:190). 
1979:190). Volgens Weren (1979:188) kan Matteus dus nie as 'n "apokaliptikus" beskou word nie ${ }^{34}$ omdat die etiek in Matteus nie dui op passiwiteit nie. ' $n$ Passiewe houding sou gepas wees vir mense wat sterk bewus is van die eindtyd wanneer die onregverdige aiōn deur God se oordeel getref sal word en wat sal lei tot die regverdiging van die regverdiges.

Aan die ander kant, as 'n mens apokaliptiek sou sien as 'n lewenshouding sonder etiese appèl, ${ }^{35}$ is die gevolg dat dit nie moontlik sou wees om apokaliptiek as een van verskeie "eskatologieë" in die eerste-eeuse oos-Mediterreense wêreld te reken nie. Jesus se voorstelling van God se koninkryk sou ook dan nie as nou verweef binne die konteks van "etiese eskatologie" gesien word nie. Die erkenning van die plek en rol van 'n begrip soos "etiese eskatologie" as 'n alternatief op "apokaliptiese eskatologie" vat egter niks weg van wat ons weet rakende die kenmerke van "Christelike" apokaliptiek soos ons dit onder andere in die boek Openbaring en in die "apokaliptiese" passasies in die Sinoptiese Evangelies aantref nie. Die kern hiervan is dat God op die hemelse troon sit, met Christus as die eskatologiese Seun van die mens aan God se regterhand. ${ }^{36}$ So 'n apokaliptiese siening onderbou die geloof dat God regverdig is, dat God se oordeel nie alleen as iets in die toekoms verwag word nie, maar ook iets is wat reeds 'n gegewenheid is en finaal by die paroesie geopenbaar sal word. Hierdie geloofsoortuiging is met ander woorde reeds 'n gegewe vir alle regverdiges wat gehoorsaam wag vir die finale oomblik van die paroesie - dit wil sê vir diegene wat die profetiese verkondiging oor die laaste oordeel hoor en aanvaar.

\footnotetext{
34 “.., Matteus (kan) niet beschouwd worden als een apocalypticus” (Weren 1979:188, 236; contra Hadfield 1959:128-132 en Treese 1958:281).
}

${ }^{35}$ So byvoorbeeld, meen J T Sanders (1975:115) dat dit jammer is dat ons vandag 'n herlewing van juis daardie soort van Christenskap beleef wat ons in Openbaring vind. Tog meen Sanders dat hierdie herlewing op ' $n$ ironiese wyse die voordeel het dat dit mens toelaat om baie duidelik te sien tot watter mate so 'n posisie eties totaal arm is. Wanneer mense vandag bewustelik en opsetlik alle verpligtings versuim om te help om die sosiale, internasionale en individuele probleme van ons tyd te oorkom, en daarop aandring dat sulke probleme nie die individu se taak is nie, omdat Jesus eersdaags kom, dan het ons volgens Sanders die ergste vorm van 'n onttrekking van etiese verantwoordelikheid (my parafrase van Sanders).

${ }^{36}$ Hierdie uitdrukking veronderstel, volgens Hengel $(1995: 183,188)$, idees wat gemeenskaplik was aan meerdere groepe in die vroeë Christendom. Dit kom voor in onder andere Matteus 19:28; Lukas 22:30; 1 Korintiërs 6:2 v en Openbaring 20:4 e v. Hengel meen dat die parallele tradisie dat outoriteit aan die Seun van die mens (oftewel die Messias) as redder van God se volk gegee word om te oordeel, van die meer belangrike aspekte van hierdie motief is. Dit word aangetref in 1 Henog se gelykenisse en in die besonder in dit wat Jesus en sy eerste volgelinge geleer het (bv in Matt 25:31e v). So byvoorbeeld is Matteus 19:28 volgens Hengel waarskynlik afhanklik van dié tipe taagebruik wat in die Henoggelykenisse gevind word. 
In Matteus 10:32 word daar 'n beroep op almal gedoen om Christus te bely as die komende Seun van die mens, en dit beteken dat Christus gevolg sal word, selfs tot in die dood. Met hierdie profetiese proklamasie verduidelik Matteus die dissipels se sending na Israel in eskatologiese terme. ${ }^{37}$ Aan die dissipels word daar in Matteus 10:23 gesê dat hulle nie daarin sal slaag om die hele Israel voor die koms van die Seun van die mens te bereik nie. Anthony Saldarini (1994:78) interpreteer hierdie opmerking teen die agtergrond dat Matteus hier konflik binne die Joodse gemeenskap in gedagte het. Volgens hom sou dit betrekking hê op die keiserlike owerhede, maar Matteus het die model van dit wat met Jesus gebeur het, in gedagte. Dit is duidelik dat Matteus se gemeenskap aanvaar het dat hulle nog teëspoed en lyding te wagte kan wees. ${ }^{38}$ Hoop op vindikasie het egter begin vervaag, en daarmee saam die hele struktuur van apokaliptiese teologie. Op grond van die geloof in die opstanding het Matteus se gemeenskap gewag op die hernuwing van die "twaalf stamme" van Israel (vgl Strecker [1966] 1971:33; Stanton 1992:10-12; Luomanen 1998:278; Yueh-Han Yieh 2004:287), terwyl hulle daarna gestreef het om die Tora in Jesus se terme te handhaaf.

\section{3. 'N KAMEE OOR ESKATOLOGIE EN APOKALIPTIEK}

Voordat ons in die artikel daartoe oorgaan om klem te lê op die korrelasie tussen die voor-Pase Jesus-sending en die na-Pase dissipels-sending en daardeur die aard van Matteus se eskatologie verklaar, is dit nodig om kortliks aandag te gee aan die terme "eskatologie" en "apokaliptiek". Ons het reeds daarop gewys dat apokaliptiek nie slegs betrekking het op 'n bepaalde literêre genre nie. Dit is ook 'n sosio-religieuse en kulturele verskynsel. Die onderskeid tussen letterlike en figuurlike taal wat dikwels teen die agtergrond van die apokaliptiese genre gemaak word, kan ons daartoe verlei om te dink dat mense in die Bybelse tyd voorstellings in apokaliptiese literatuur as "bonatuurlik" beskou het in teenstelling met die natuurlike wêreld. ${ }^{39}$

Om apokaliptiese denke uit die eerste-eeuse Mediterreense wêreld te begryp vra van die interpreteerder 'n etno-metodologiese sensitiwiteit sodat

\footnotetext{
${ }^{37}$ Aan die dissipels word in Matteus 10:23 gesê dat hulle nie daarin sal slaag om die hele Israel te besoek voor die koms van die Seun van die mens nie.

${ }^{38}$ In die lig van Matteus 10:22 en 24:13 wys die "eskatologiese wet" (lex talionis) daarop dat die aanvaarding van ellende en lyding 'n "bewys" was van toekomstige redding deur God. Ellende en lyding word egter gevolg deur redding. Matteus 10:23 hou met hierdie idee nou verband.

${ }^{39}$ Dit was op grond van die vertaling van die werke van Pseudo-Dionysus na Latyn in die negende eeu dat die woord "bonatuurlik" in die teologie van die Westerse Christendom ingebring is (Saler 1977:38, 46).
} 
die verskil tussen die ervarings van mense in 'n Eurosentriese konteks en mense van die wêreld rondom die Middellandse See in die eerste eeu ernstig geneem sal word. Streng gesproke behels apokaliptiek die siening dat God se "nuwe tyd" binnekort gaan kom en dat katastrofes van kosmiese omvang dit sal laat begin. Die skrywers van Nuwe-Testamentiese geskrifte het hierdie verwagting in wisselende grade gekommunikeer. Wat vir my doeleindes in hierdie essay belangrik is, is die "betekenis" wat tyd as begrip in die konteks van "apokaliptiek" en "eskatologie" kan hê. Vanuit 'n sosiaal-wetenskaplike perspektief onderskei Bruce Malina (1996:192-193) tussen ervaarde tyd ("experienced time") en ver-beelde tyd ("imaginary time").

Dit wat ver-beeld word, hou verband met dit wat 'n mens ervaar. ${ }^{40}$ Beskrywing van die wêreld buite ervaring, byvoorbeeld die wêreld ná iemand se dood, skep die indruk dat hierdie ervaring by mense binne die konteks van sekere kulture, soos die eerste-eeuse Mediterreense, 'n soort "verlenging" vorm van die lewe wat in die voor-doodse wêreld ervaar word. ${ }^{41}$ Wat teoloë en eksegete soms "apokaliptiese eskatologie" noem (bv Sim 1996:31-53, 5369) verwys na 'n raamwerk van denke gevul met ervarings van so 'n "verbeelde tyd". Voorstellings van hierdie denke getuig van 'n bewussyn wat in ervarings manifesteer deur middel van visioene of hemelse oudisies wat soms 'n droom- of transagtige toestand daarstel. Alhoewel hierdie apokaliptiese bewussyn vir rasioneel Eurosentries-georiënteerde persone dui op die wêreld van abstrakte denke (wat gedurende die periode van modernistiese Aufklärung negatief as irrasioneel, primitief en soms mities beoordeel is - kyk o a Walsh 2001:128-130), het mense in die antieke tyd so 'n bewussyn en gepaardgaande voorstellings as "natuurlik" beskou.

Benewens die feit dat die "tyd" in apokaliptiese terme, in Philo Judaeus se woorde, so "geheimsinnig, vreemd en nuut en buite die wêreld

\footnotetext{
${ }^{40}$ Die verskil tussen ervaarde tyd en ver-beelde tyd word deur Johann Kreuzer (2005a) beskryf as aan die een kant, tye wat met "aardsgebondenheid" te doen het en aan die ander kant, tye wat hy die "goue tyd" noem. Op hierdie wyse praat Kreuzer van die tye (die Zeitalter) wat betrekking het op die buite-wêreldse as die "goue eeu" en hierdie-wêreldse tyd (die der Jetztzeit) as "dié van die aardgeborenes" ("das goldene und das der Erdgeborenen"). Die "goue tydvak" vorm 'n "teenutopie van 'n mitiese eenheid" wat terugstrek van die ervaarde "natuurgebeure van die kosmos" (rückwärts gewandte Gegenutopie einer mythischen Einheit mit dem Naturgeschehen des Kosmos). Die "tydvakke sonder tyd" (Zeitalter ohne Zeit) - dit wil sê die "goue tyd" voor geboorte en na dood is as 't ware "voor-historiese hipoteses" (vorgeschichtliche Hypothesen) wat poog om die toestand in die huidige wêreldorde te verklaar. So kom daar 'n ooreenstemming tussen hierdie-wêreldse en die buite-wêreldse ervarings tot stand.

${ }^{41}$ Kyk Aristotoles, Physica 4.10.218a.4-9: "Dele van tyd was, en ander moet nog kom, en niks daarvan is nie. Want wat 'nou' is, is nie 'n deel nie: 'n deel is 'n mate van die geheel, wat uit dele moet bestaan. Tyd word egter nie gereken om uit 'noue' te bestaan nie" (eie vertaling) (vgl Neyrey \& Rowe 2008:311, voetnota 12).
} 


\section{"Op die aarde net soos in die hemel"}

van sig" is, ${ }^{42}$ beklemtoon resente studies oor "apokaliptiese eskatologie" 'n mentaliteit van sektarisme (vgl Saldarini 1991:44-48; Carter 2000:43). ${ }^{43}$ Wat hiermee bedoel word, is dat ' $n$ minderheidsgroep in krisistye gemarginaliseer word. Omdat 'n sekte losgemaak is van 'n "ouerliggaam" en sodoende gemarginaliseer word, is 'n sekte geneig om slegs van twee kante van 'n saak bewus te wees en om dualisties te onderskei tussen reg en verkeerd, die goddelike en die sataniese, 'n hierdie-wêreldse en 'n buite-wêreldse.

Apokaliptiek is daarom aan die een kant gekenmerk deur pessimisme en determinisme, en aan die ander deur hoop. Die huidige bestel is 'n erbarmlike bestel, terwyl die transendentale bestel na hierdie een vol vreugde is. Sodanige pessimisme en determinisme hou sterk verband met die oortuiging dat die verloop van die geskiedenis verander kan word - tot voordeel van die individu self en vir ander - deur middel van die gebede en martelaarskap van die regverdiges (Malina 1996:192-193).

In die Matteusevangelie word hierdie apokaliptiese agtergrond op 'n bepaalde wyse aanwesig gemaak (kyk Van Aarde 2005:7-9). Soos elders breedvoeriger uitgewerk, verteenwoordig my rekonstruksie van hierdie konteks dat Matteus as narratief afkomstig is uit die gebied van Noord-Galilea

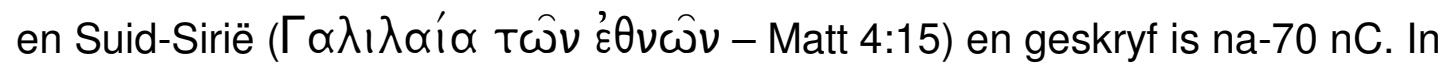
hierdie milieu was daar konflik tussen die grammateus Matteus en die "dorpskrifgeleerdes" wat besig was om die eerste fase van 'n "Farisese rabbinaat" te vestig.

Myns insiens is die Matteusevangelie 'n produk van hierdie skrifgeleerde aktiwiteit in die konteks van die "hervestiging" van plattelandse dorpies na afloop van die Joodse oorlog en na die vernietiging van die tempel in Jerusalem in $70 \mathrm{nC}$. Die Israels-georiënteerde gemeenskappe in die dorpies het gesukkel om die verlies van beide die tempel en Jerusalem te verwerk. Aangesien die "stad van God" nie meer bestaan het nie, moes hulle God se teenwoordigheid vind in die omgewing van hierdie

\footnotetext{
${ }^{42}$ Volgens Philo Judaeus, De mutatione nominum 267 (in Neyrey \& Rowe 2008:306, voetnota 10 ), word hierdie soort "tyd" nie "gemeet aan die opkoms en ondergang van die son en die maan nie, maar dit is iets waarlik geheimsinnig, vreemd en nuut, buite die wêreld van sig en die [ander] sintuie, in die ryk van die nie-liggaamlike en verstaanbare, en die model en

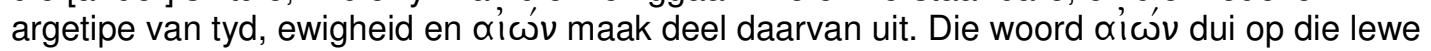
van die wêreld van denke, omdat tyd (Xpóvos) die lewe van die waarneembare is" (eie vertaling).

${ }^{43}$ Wat spesifiek die debat rakende Matteus betref, kyk onder andere Repschinski (2000:5056); Duling (1993:642-671;1995a:159-182; 2002:520-575).
} 
dorpsgemeenskappe waar hulle gewoon het. ${ }^{44}$ Te midde van Romeinse eksploitasie het skrifgeleerdes betrokke by die dorpsrestourasie geraak. ${ }^{45}$ Konflik het tussen twee groepe skrifgeleerdes ontstaan: die volgelinge van Jesus, wat Jesus as Messias bely het, en ander Israeliete wat vasgeklou het aan ' $n$ tradisionele messiaanse siening. Die konflik het gefokus op die interpretasie van die Tora: Jesus as die "tweede Moses" wat die Tora vervul het of die tradisionele Mosaïese siening soos gereguleer deur die tempelkultus. ${ }^{46}$

Matteus reflekteer 'n spanning by tempel-georiënteerde Israelse gelowiges as gevolg van die druk wat heidense magte op die tempelkultus na $70 \mathrm{nC}$ geplaas het sowel as 'n spanning by lede van die ekklēsia as gevolg van die druk wat hierdie gelowiges op die Jesus-volgelinge vanweë die transformasie van die tempel en sinagoge geplaas het. Oor die algemeen kan daar gesê word dat die apokaliptiese krisis vergroot is omdat die veronderstelde verhouding tussen dade en vergelding nie gerealiseer het nie. Die "goddeloses" is nie gestraf nie en die "regverdiges" is nie die ooglopende oorwinnaars nie. "Ervaarde tyd" is dus as gevolg van hierdie verleentheid geprojekteer na 'n "ver-beelde tyd" waar God beheer uitoefen - met ander woorde God se koninkryk.

In Matteus verwys die uitdrukking "koninkryk van die hemel" slegs in 'n baie spesifieke sin van die woord na die einde van die wêreld wat in die

\footnotetext{
${ }^{44}$ Die Jesusbeweging in Galilea en die werk van vroeë rabbi's na- $70 \mathrm{nC}$, wat Horsley (1996:181-184) die "earlier scribes and sages" noem, kan as 'n vernuwing van dorpsgemeenskappe beskou word. Nadat die tempel vernietig is, het die Farisese skrifgeleerdes hulleself in plekke soos Jamnia (in Judea), Galilea en Sirië herorganiseer. Daar het hulle in die huishoudings van die dorpe probeer om die ou waardesisteem van die tempel te repliseer, veral regulasies oor die hiërargie in die samelewing en die reinheidsideologie wat vir die tempelgemeenskap gegeld het. 'n Soortgelyke hernuwing van die dorpsgemeenskappe is 'n aktiwiteit wat ook die Jesus-groepe onderneem het. Die waardesisteem wat hulle wou implementeer, is gebaseer op Jesus se alternatiewe interpretasie van die Tora.

${ }^{45}$ Die argumente van persone soos Overman (1990:158-159) en Saldarini (1994:2) ten gunste van 'n Galilese lokaliteit vir Matteus, word volgens my deur Kloppenborg (2000:171178) se ondersoek na die sosiale lokaliteit van $Q$ ondersteun. Dit is myns insiens moontlik om Kloppenborg se argumente oor "skrifgeleerde aktiwiteit" rakende die onstaan van $Q$ op Matteus toe te pas en wat sy "onder-Galilea"-teorie betref, dit met "bo-Galilea en suid-Sirië" ten opsigte van Matteus te vervang.

${ }^{46}$ Volgens Käsemann het die Paas-gebeure gelei tot die oorsprong van hierdie "teologie". Eers was daar dié van 'n klein Jesus-groep wat kom uit die Israelse tradisie wat later ontwikkel het tot 'n sekte binne die "groot kerk". Uiteindelik het die Matteaanse gemeenskap verdwyn en slegs baie min tekens daarvan het agtergebly (bv Matt 16:19). Hoewel ek met Käsemann saamstem dat Matteus met die vroegste Jesus-groep in Jerusalem raakpunte het en selfs in 'n sekere sin daaruit voortgekom het, verskil ek van hom met betrekking tot sy grondliggende tese dat Matteus sowel 'n "anti-Paulinistiese Antiogieense" geskrif as 'n "intraChristelike" twispunt daarstel.
} 
toekoms op die skepping wag. Dit is met betrekking tot hierdie idee van die "einde van die wêreld" dat die woord "eskatologie" gebruik word. ${ }^{47}$ Soortgelyk aan die "ver-beelde" tyd van die "goue eeu" in die verre verlede "toe diere kon praat" (Bourdieu 1963:60), verwys die verre toekoms na die "ver-beelde" tyd wanneer die immanente wêreld vervang sal word deur die transendentale wêreld van God. ${ }^{48}$ In 'n sekere sin beteken God se wêreld 'n volmaakte wêreld, 'n goddelike utopie in teenstelling met ons kortstondige en korrupte wêreld. In Matteus word laasgenoemde weerspieël ${ }^{49}$ in terme van die konflik in suid-Sirië/noord-Galilea na-70 nC tussen dorpskrifgeleerdes in die Jesusgroepe en die sinagoge-skrifgeleerdes onder die Fariseërs.

\footnotetext{
${ }^{47}$ Een van die resultate van 'n studie van die formatiewe stadia van eerste-eeuse godsdiensgmeenskappe is ons bewuswording van anakronistiese interpretasie. Teoloë raak maklik gewoond aan terminologie waarvan mense aanneem dat dit verwys na verskynsels in Bybelse tye, maar wat in werklikheid in daardie tyd onbekend was. Die term "eskatologie" is so 'n teologiese begrip uit die laat moderne tyd, eintlik 'n "theologoemenon" omdat dit slegs in teologiese kringe gebruik word (vgl Lauer, R H 1981. Temporal man: The meaning and uses of social time).

${ }^{48}$ In sy boek Windows on the world of Jesus: Time travel to ancient Judea toon Bruce Malina (1993:156) aan dat mense in die antieke tyd rondom die Middellandse See min belang gestel het in 'n abstrakte toekoms en dat hulle basies hede-georiënteerd was (kyk ook Malina 1989:1-31). Hierdie inligting is bevestig deur volgende insigte uitgespreek in die artikel van die sosioloog Pierre Bourdieu (1963:55-72): "Die tydsverloop waaruit die hede bestaan, is die geheel van ' $n$ aksie gesien in die eenheid van 'n persepsie wat beide die verlede wat onthou word en die verwagte toekoms insluit. Die 'hede' van 'n aksie omvat, buiten die waargenome hede, 'n horison van die verlede en van die toekoms verbind met die hede omdat hulle albei aan dieselfde betekeniskonteks behoort" (my vertaling) van Bourdieu (1963:55). Volgens Jerome H Neyrey en Eric Rowe (2008:300) verwys hierdie "betekeniskonteks" (met ander woorde 'n sosiale konstruk wat in 'n narratiewe diskoers vertel word - A $\vee A$ ) na dieselfde verskynsel waarna Bruce Malina (1989:11-14) verwys as "ervaarde tyd". Christopher Gosden (1994:2-5) onderskei sodanige "ervaarde tyd" van "gemete tyd". In Mediterreense konteks, volgens Bourdieu (1963:61-62), is toekoms - hoewel geskei van die ervaarde tyd van die hede - op dieselfde manier as die hede waargeneem. Toekoms en hede is so organies as eenheid verbind.
}

${ }^{49}$ Die polemiek tussen Jesus se onderwysing en dié van die Fariseërs in die evangelietradisie - soos in Q en in Matteus wat vir Q as 'n bron gebruik het (vgl Kloppemborg 2000:200 e v moet egter nie op 'n anakronistiese wyse gesien word asof twee gevestigde instellings, 'n "kerk" en 'n "sinagoge", in konflik met mekaar sou wees nie. Die strydige belange was eerder die resultaat van 'n proses van institusionalisering wat in die opset van die dorpsgemeenskappe in twee rigtings ontwikkel het. In die Jesus-tradisie in die Evangelies word Jesus se onderwysing in sinagoges in Galilea deur Farisese skrifgeleerdes bestry (kyk 0 a Mark 1:21, 27; 2:1, 6). Die konteks van hierdie vroeë skrifgeleerde-aktiwiteit onder sowel Jesus-volgelinge as die Fariseërs was eerder dié van die bet-midrash (formatiewe Judaïsme) as dié van die bene ha-knessett (normatiewe Judaïsme). Vanaf die tweede eeu nC het die sinagoge begin om apart van die administrasie van dorpies te funksioneer (kyk Cohen 1992:157-173; Levine 1992:201-222). 


\section{SEKWENSIES VAN TYD IN MATTEUS}

Käsemann was dus myns insiens heeltemal in die kol toe hy gesê het dat Matteus se gemeenskap progressief kleiner geword het. Hy was ook reg toe hy aangedui het dat die historiese Jesus homself nie as die apokaliptiese Seun van die mens gesien het nie. Matteus (soos Markus en die tweede redaksionele versie van $Q$, asook Lukas) het hierdie tradisie van die eerste Jesus-groep in Jerusalem oorgeneem (kyk Van Aarde 1999:795-826; 2002:118-142). Myns insiens was Käsemann egter op die verkeerde spoor toe hy die stelling gemaak het dat Matteus se gemeenskap in die konteks van die frühkatholische Christelike gemeenskap verdwyn het - alhoewel die "Eerste Evangelie" as sulks in hierdie konteks bekend geword het en wyd deur die "katolieke kerk" aanvaar is. ${ }^{50}$ Dit blyk egter dat Matteus se gemeenskap 'n ander geskiedenis gehad het. Myns insiens behoort die Matteus-gemeenskap se "kleiner word" in getal en waarde toegeskryf word aan die kragte van marginalisering binne die konteks van formatiewe Judaïsme. ${ }^{51}$

Dit is teen hierdie historiese agtergrond dat Matteus die "narratiewe wêreld" van sy diskoers geskep het. In sy plotintrige ontwikkel Matteus 'n kontinuïteit sowel as 'n analogie tussen die voor-Pase Jesus-sending (die eerste "sekwensie van tyd") en die na-Pase dissipels-sending (die tweede "sekwensie van tyd"). Deur middel van die redaksionele proses van tradisieoorlewering, verandering en herinterpretasie (mondeling en geskrewe), verplaas Matteus Jesus se era na die era van sy gemarginaliseerde gemeenskap. Dit is op so 'n manier gedoen dat twee "wêrelde" tegelykertyd as 'n narratiewe eenheid in die plot van die narratiewe diskoers opgeneem word.

Matteus se narratief gaan dus oor mense en dinge uit 'n vroeëre tyd terwyl die latere periode waarin die diskoers ontstaan het en waarin dit gekommunikeer is, binne die konteks van die "vroeëre tyd" deursigtig is. ${ }^{52}$

\footnotetext{
${ }^{50}$ In hierdie konteks het Matteus se groep (asook Ebionitiese Jesus-groepe in TransJordanië) verdwyn. As 'n apokalipties-messiaanse beweging - en dus reeds 'n gemarginaliseerde minderheid in die konteks van die formatiewe Farisese rabbinaat - sou Matteus se gemeenskap slegs met moeite op die grens tussen Galilea en Sirië na die BarKochba opstand oorleef het.

${ }^{51}$ Gedurende die tydperk van formatiewe Judaïsme lyk dit asof die skrifgeleerde wat vir die Matteusevangelie verantwoordelik was, in konflik was met sommige van die skrifgeleerdes van die Galilese/Siriese dorpsadministrasie (wat kop in een mus was met die élite van die voormalige Jerusalemskrifgeleerdes - vgl Orton 1989:49). As 'n grammateus wat 'n "dissipel" van die "koninkryk van die hemel" (Matt 13:52) geword het, kon die skrywer van Matteus na alle waarskynlikheid sy herkoms in Jerusalem gehad het.

${ }^{52}$ Hierdie interpretasieteorie staan as my "transparantteorie" bekend (Van Aarde 1994:117126).
} 
Matteus se narratief verhaal hoe God vanuit die koninkryk van die hemel by Israel betrokke is. Maar, in plaas daarvan om in die tempel te manifesteer die tempel wat in die verlede God se woonplek onder God se volk was, maar korrup geraak het (berig in o a Matt 21:12 e v) as gevolg van die optredes deur die tempelowerhede wat as besetters van Moses se kateder beskryf word (Matt 23:2), het God op 'n ander manier God self laat manifesteer. God het God-met-ons geword in Jesus, die Messias / Seun van die mens - wat "groter is as die tempel" (Matt 12:6). Die doel van hierdie Jesus-sending was

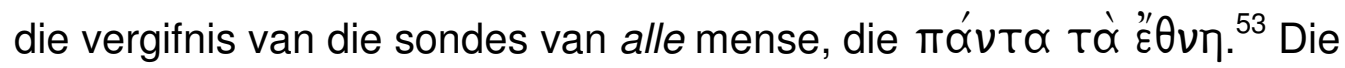
uitdrukking "vergifnis" kom neer op heling van gemarginaliseerdes wat van God se teenwoordigheid uitgesluit is - dit wil sê 'n akkommodering in die geloofsgemeenskap. Uit Matteus se oogpunt het Jesus diegene wat "vergifnis" ontvang, gesien as die nuwe "eskatologiese" gemeenskap. ${ }^{54}$ Kronologies gesien, is daar drie "sekwensies van tyd" in Matteus aanwesig. Oppervlakkig gereken, lyk dit of die na-Pase dissipels-sending na "al die nasies" plaasgevind het in die "tyd" wat volg op die voor-Pase Jesussending. Hierdie siening is daaraan toe te skryf dat die plotintrige van Markus en Lukas só anders lyk as dié van Matteus. Waar Markus skryf teen die agtergrond van 'n verwagting van Jesus se vroeë terugkeer na opstanding, daar begin Matteus om voorsiening te maak vir 'n moontlike uitbly van Jesus se "terugkeer" deurdat Matteus die dissipels-sending beklemtoon. Hierdie tema is wel in Markus aanwesig (bv in Mark 13:10), maar in Matteus verteenwoordig die dissipels-sending 'n onafhanklike tydperk met 'n funksie wat tipies is in Matteus, naamlik om van alle mense dissipels te maak (kyk

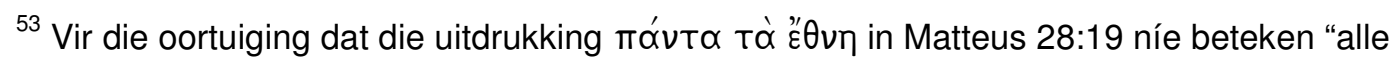
nasies behalwe die Jode" nie, vergelyk onder andere Combrink (2007:19, 224). Die "alle nasies" behoort inderdaad as volledig inklusief verstaan te word (kyk Van Aarde 2007:419).

${ }^{54}$ Meer as 'n dekade terug het Graham Stanton reeds aangedui dat ons in Matteus-studies afstand moet doen van begrippe soos die "ware Israel" en selfs die "nuwe Israel". Volgens Stanton (1992:11) praat Matteus eerder van 'n "nuwe volk" (Matt 21:43) - inderdaad 'n "derde groep" (tertium genus) teenoor beide die "Jode" en die "heidene". Hy is egter van mening dat Matteus sy evangelie gedeeltelik geskryf het om sy lesers se vasberadenheid om aan te hou om die heidene te aanvaar, te versterk (Stanton 1992:281). Vanuit 'n effens ander perspektief kom Donald Senior (2001:18) tot die slotsom dat Matteus se uiteindelike doel die realisering was van 'n ekumeniese visie van die vereniging van "Joodse" en "heidense" Jesus-volgelinge in één gemeenskap. Anthony J Saldarini (1994) beskou die Matteus-groep egter as 'n brose minderheid wat hulleself nog steeds as "Joods" beskou het en nog steeds deur ander met die "Joodse" gemeenskap geïdentifiseer is. Wanneer hy dus van die "Matteus-gemeenskap" praat, gebruik Saldarini die begrip "Christelik-Joods" eerder as "Joods-Christelik". Soortgelyk redeneer Paul Hertig (1998) dat dit Matteus se doel was om tot voordeel van die "Jode", die "Joodse Christendom" stewig binne die konteks van Judaïsme te grond en tegelykertyd die universele karakter van die Jesus-beweging wat "heidene" insluit, te handhaaf.
} 
Matt 28:16-20) (vgl Marxsen 1959:63f). ${ }^{55}$ Wat Lukas betref, het ons eksplisiet die berigte oor die sending van die dissipels uitgevoer deur die apostels, soos in Handelinge berig.

Op die oppervlak van die struktuur wat Matteus se plot betref, kan ons dus tot die slotsom kom dat daar in Matteus drie "sekwensies" aanwesig is: (1) die "opeenvolging" van die gebeure voor-Pase, (2) die "opeenvolging" van die gebeure na-Pase tot die paroesie en (3) die "opeenvolging" wat met die paroesie begin. Al drie van hierdie sekwensies is nou geïntegreer in Matteus se plotintrige. Terwyl daar in Markus slegs twee episodes (Mark 1:15; 14:49) voorkom wat verband hou met die voorspelling dat die "tyd van Jesus" die vervulling verteenwoordig van 'n belofte ( $\mathrm{d}$ w s die "tyd van die profete", veral betuig in die Hebreeuse Bybel), speel die begrip "vervulling" 'n baie meer prominente rol in Matteus. Net soos Matteus 'n verband tussen die tyd van Jesus voor-Pase en die tyd van die skrywer en sy gemeenskap na-Pase daarstel, lê Matteus ook 'n verband tussen die "tyd van Jesus" en die "tyd van Moses en die profete" (soos veral in die Hebreeuse Bybel vertel). Hierdie verband word in die besonder uitgedruk in die vervullingsaanhalings. Met ander woorde, die afsluiting van die "tyd van Jesus" verwys na 'n vorige begin, naamlik dié van "Moses en die profete" (dié van die Hebreeuse Bybel) (Marxsen 1959:64).

Wat steeds egter 'n vraag is, is die kwessie wat die aard van hierdie verband en kontinuïteit is wat in die vervullingsitate uitgedruk word. Dit geld ook die ander aanhalings uit en toespelende verwysings na die Hebreeuse Bybel in Matteus (vgl Senior 1976:670). 'n Belangrike besprekingspunt is om daardie punt in Matteus se narratiewe struktuur te vind waar die eerste sekwensie oorgaan in die tweede. ${ }^{56}$

\footnotetext{
${ }^{55}$ Wat fundamenteel in Willi Marxsen se teorie belangrik is, is die feit dat daar in Matteus 'n onderskeid getref moet word tussen die "tyd van die Ou Testament" en die "tyd van Jesus" of soos Marxsen dit beskryf het: die tyd van Jesus is 'n tydvak tussen twee ander. Vrae wat gedebateer kan word is dié met betrekking tot die aantal sekwensies wat in Matteus herken kan word, die geartikuleerde punt waar die een sekwensie eindig en 'n ander begin, en die plek en aard van die "tyd van die Ou Testament" in Matteus se plotintrige.

${ }^{56}$ Gedurende die bloeitydperk van die vorige generasie redaksioneel-kritiese eksegese, het persone soos Strecker (1966) en Walker (1967) 'n posisie ingeneem wat in teenstelling gestaan het met die posisie van eksegete soos Trilling (1969a, 1969b) en Meier (1976). Strecker en Walker stem saam dat daar drie temporele fases in Matteus onderskei kan word. Walker (1967:115) verwys na hierdie drie temporele fases as die "voorgeskiedenis van die Messias", wat begin het by Abraham, die "geskiedenis van die roeping van Israel" wat bestaan uit die bediening van Johannes die Doper as die voorloper van die Messias en Jesus self as die Mitte der Mitte, en uiteindelik die "geskiedenis van die sending aan die heidene" wat begin met die kruisiging en opstanding van Jesus en strek tot die oordeelsdag - en dus gedeeltelik ooreenstem met die tyd van die skrywer van die Matteusevangelie. Strecker (1966:184-188) verwys na hierdie drie temporele fases as die "tyd van die vaders en die profete", die "tyd van Jesus" en die "tyd van die Heidenkirche". Na Jesus se dood en opstanding het die "tyd van die profete en van Jesus" oorgegaan in die "eskatologiese tyd".
} 
Om hierop 'n antwoord te vind, is dit belangrik om vertroud te wees met die uitdrukkings wat Matteus gebruik om na hierdie opeenvolging te verwys, veral die opeenvolging van die gebeure na Pase tot met die paroesie. ${ }^{57} \mathrm{Die}$ opeenvolging wat volg op die paroesie staan onder andere bekend as $\eta ் \omega n$

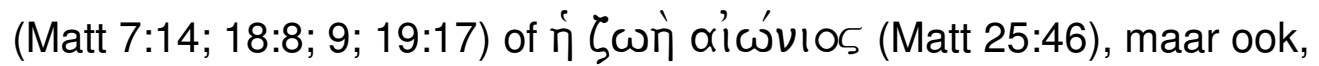

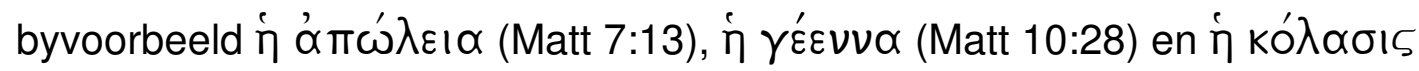
o'í́vios (Matt 25:46). Ander "plekke" wat na hierdie "tyd" verwys, kan in Matteus 3:12; 5:22; 18:8, 9; 24:51; 25:10, 23, 30, 34, 41 en 26:28 gevind word. Dit is die "tyd" wat met die paroesie begin.

In vergelyking met die ander Sinoptiese Evangelies word daar in Matteus alleen na hierdie derde sekwensie verwys (hoofsaaklik in gelykenisse), maar in die narratiewe struktuur word daar nie daarop uitgebrei nie. Dit is waarom die plot van Matteus alleen twee basiese tydsvlakke verteenwoordig, naamlik die sekwensie van die voor-Pase gebeure en die sekwensie van die na-Pase gebeure.

Sekere frases wat tyd aandui, het in Matteus betrekking op die "tyd wat sluit" wanneer Jesus uit die dood opstaan en aan sy dissipels verskyn en hulle

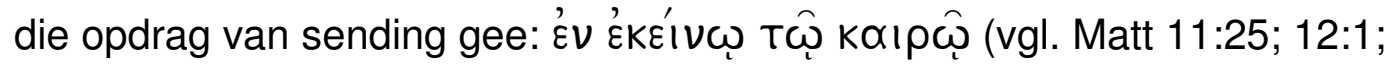

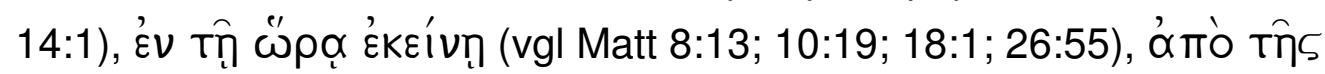

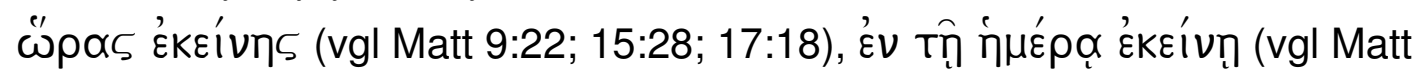

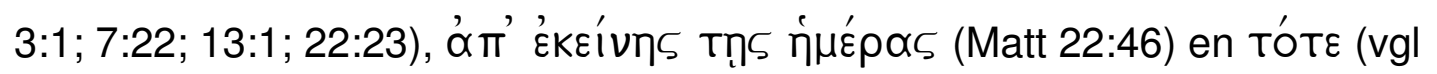
Matt $2: 16 ; 3: 13 ; 4: 1)$. Die deelwoorde wat "tyd" gebruik om omstandighede in Matteus $2: 1,13,19$ en $4: 12$ aan te dui, kan by die bogenoemde tydsfrases gevoeg word. Die volgende frases dui weer op die einde van die dissipels se

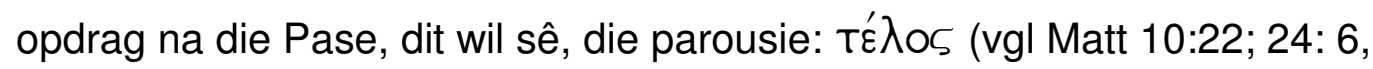

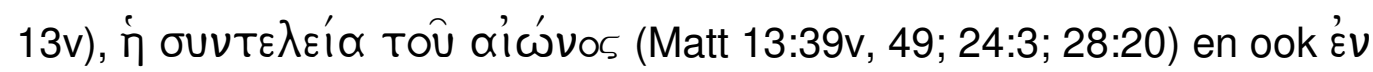

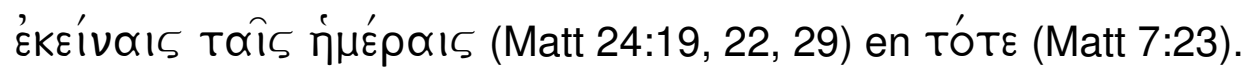

\footnotetext{
${ }^{57}$ Anders as Strecker en Walker, onderskei Kingsbury (1973:471) nie drie temporele fases nie, maar twee. Volgens hom is daar die "tyd van Israel", wat voorbereidend en profeties is vir die koms van die Messias, en daar is die "tyd van Jesus". Gedurende die laasgenoemde era vind Israel vervulling as "ware" volk van God. Volgens Kingsbury is daar streng gesproke geen tyd van die kerk in Matteus se persepsie van die geskiedenis nie, want hierdie tyd word opgeneem in die "laaste dae" wat deur Johannes en Jesus ingelui is. Daarom verskil Kingsbury van Strecker en Walker nie met betrekking tot die begin van die "tyd van Jesus" nie, maar met betrekking tot die einde van hierdie "tyd". Hy is van mening dat daar geen wending van tyd deur Jesus se dood en opstanding plaasgevind het nie, maar dat die "eskatologiese tyd" ten volle saamval met die "tyd van Jesus". Volgens hierdie siening skei die elemente belofte (Ou Testament) en vervulling (Jesus) die twee temporele tydvlakke. Kingsbury (1973:470; vgl Strecker 1966:87) bou sy argument veral op die tydformule $\varepsilon v$

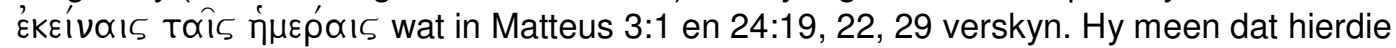
tydformule 'n uitsluitlik "eskatologiese" konnotasie het. Dit verwys volgens hom na daardie periode wat die "voltooiing van die tyd" en die paroesie van Jesus, die Seun van die mens, voorafgaan.
} 


\section{ESKATOLOGIE IN MATTEUS EN INTERTEKSTE}

Met betrekking tot Matteus se eskatologie is Donald Hagner ([1994] 1996:174176) se bydrae tot die Festschrift vir Robert H Gundry (1982) besonder van belang omdat hy 'n goeie oorsig bied van die relevante tekstuele getuienisse en teologiese vraagstukke. ${ }^{58}$ Hagner wys daarop dat Matteus se tydsbegrip daarop neerkom dat die begin van die einde aangekondig is, en dat hierdie fundamentele kompleksiteit verband hou met beloftes betuig in die Hebreeuse Bybel (bl 176), die vernietiging van Jerusalem, die geïmpliseerde tussenperiode (bl $175 \mathrm{ev}$ ) en die koms van die Seun van die mens (bl $174 \mathrm{ev).}$

Ek stem veral met Hagner se bevinding aan die einde van sy essay saam dat die grootste uitdaging van enige poging om Matteus se eskatologie op 'n oorsigtelike wyse te beskryf, daaruit bestaan dat die verskeidenheid ander sake in die Matteusevangelie wat met eskatologie verband hou, nie deur die eksegeet uit die oog verloor sal word nie. Dit sluit in om te besef dat Matteus se eskatologiese perspektief (soos ook dié van die ander evangeliste) ook met uitsprake te doen het wat nie net oor die toekoms - naby (dit wil sê, imminent) of verder weg (dit wil sê, nie 'n Naherwartung nie, maar 'n Fernerwartung vanweë die "uitbly van die paroesie) - handel nie. Die hede is ook van belang, en selfs die verlede (met ander woorde, alreeds die evangelis se eie tyd). Daar is ook verskeie opmerkings oor die nabyheid van die einde in Matteus, sowel as ander wat 'n vertraging van die einde en selfs 'n tussenperiode van beduidende lengte impliseer. Daar is ook daardie uitsprake wat eksplisiet sê dat Matteus en sy karakters in sy teks nie weet wanneer die einde gaan aanbreek nie (Hagner 1996:177).

Hagner se essay dui vir ons rigting aan deur veral vier vraagstukke in ag te neem:

- $\quad$ die rol van Moses en die profete (die beloftes in die Hebreeuse Bybel);

- $\quad$ die vernietiging van Jerusalem / die tempel;

- die tussenperiode; en

- $\quad$ die koms van die Seun van die mens.

Hagner beskryf die val van Jerusalem as "naby" en die koms van die Seun van die mens (die Messias van Israel) as iets wat behoort tot die "onbepaalde toekoms". Hy sien die optrede en onderrig van Jesus as "eskatologies" van aard omdat dit deur Matteus voorgestel word as die "vervulling van sekere beloftes" in "Moses en die profete". Hy beskryf die geïmpliseerde

\footnotetext{
${ }^{58}$ My verwysings kom spesifiek uit die herdrukte uitgawe in die SBL Seminar Papers 1996 (Scholars Press) = SBLSP 35 [1996], bls 163-181).
} 
tussenperiode (in die terme van Lukas) as veertig dae en, inderdaad, as die periode van die sending na die heidene met 'n oop einde.

Na my mening beskou Matteus die val van Jerusalem / die tempel sowel as die sien van die koms van die Seun van die mens as vooruitskouend op die kruisiging / opstanding van Jesus. Vir Matteus is hierdie twee gebeure - die vernietiging van die tempel en die sien van die koms van die Seun van die mens - deel van sy verduidelikende beskrywing van die volk Israel se geskiedenis. Hierdie "geskiedenis" word in die "Skrif" (wat Matteus op 'n midrash wyse interpreteer) geopenbaar. Die periode van "Moses en die profete" (dit wil sê die "tyd van die Ou Testament") ${ }^{59}$ word dus nie as 'n "tyd" gesien wat reeds klaar afgesluit is nie. Jesus, wat die Christus genoem word, word in die Matteusevangelie as die Seun van die mens voorgestel.

Wat dus hier in my interpretasie van Matteus se eskatologie aanwesig is, is dat die sogenaamde spanning tussen "nabyheid" van God se koninkryk en "die onbepaalde toekoms" wanneer dit finaal sal realiseer, verstaan word vanuit 'n eerste-eeuse Mediterreense tydsperspektief. Ek vind die sleutel van Matteus se begrip van tyd in die konsep wat ek die draai van die gety noem (Van Aarde 1998:16-26). Ek beskou Matteus 27:45-54 as dié plek in die diskoers van Matteus se plotintrige waar hierdie Wende der Zeit opgeteken is.

Hoewel Hagner se studie my persoonlik help om "rigting" vir my eie ondersoek na Matteus se eskatologie te vind, is daar tog 'n groot verskil in ons twee se benaderings. In Hagner se refleksie vind ons "ensiklopediese" inligting oor belangrike aspekte in die eskatologiese debat. Dit raak vrae oor die "spanning tussen die huidig gerealiseerde eskatologie" en die "ware (sic) eskatologie van die toekoms", sowel as oor die spanning tussen Naherwartung en Fernerwartung in Matteus, asook die vraag hoe lank

\footnotetext{
${ }^{59}$ Om die term "Hebreeuse Geskrifte = Ou Testament" te beperk tot die Hebreeuse kanon is wat die periode voor $100 \mathrm{nC}$ betref, anakronisties (vgl Charlesworth 1985:xxiv). Gedurende die eerste eeu voor en na die Christelike era - toe die grense van die Hebreeuse kanon nog plooibaar was - is 'n aantal pseudo-epigrafie saamgestel wat deur nóg die "Sinagoge" nóg die "Ekklēsia" buite 'n kanon beskou is (Charlesworth 1985:xxiii). Wat die getuienis in die Nuwe testament betref, geld hierdie insig ook - en waarskynlik spesifiek - die Matteusevangelie. Dit blyk byvoorbeeld dat Matteus bekend was met tradisies in onder andere 1 Henog (vgl Isaac 1983:10), 2 Barug (vgl Waetjen 1976:49-52), Die lewens van die profete (vgl Garland 1995:260; Hare 1985:393) en Pseudo-Philo (vgl Harrington 1985:302). In hierdie dokumente kom daar intertekstuele parallelle voor wat ooreenskomste met mekaar het wat veral simboliek rakende die "messiaans-eskatologiese" periode raak. 2 Barug is veral baie belangrik, want dit deel met Matteus die doel om ' $n$ "eskatologiese betekenis" aan die vernietiging van die Jerusalemse tempel en die katastrofe van die Joodse oorlog in die sewentigerjare te probeer bied. Hierdie twee geskrifte is getuienis van die opkomende "formatiewe Judaïsme" (vgl Klijn 1983:620). In beide Matteus en 2 Barug word die geskiedenis van Israel geïnterpreteer aan die hand van apokaliptiese beelde in die lig van die vernietiging van die Jerusalemse tempel (vgl Saldarini 1994:14). Dit is egter moeilik, indien nie onmoontlik nie, om te "bewys" dat Matteus afhanklik van hierdie intertekste was. Ons behoort eerder die ooreenkomste (soos wat Kliijn 1983:619 met verwysing na 2 Barug suggereer) te verklaar as die produk van 'n gemeenskaplike afhanklikheid van 'n "apokaliptiese" wêreldbeskouing.
} 
Matteus 'n "geïmpliseerde tussenperiode" veronderstel. Die probleem wat ek met Hagner se benadering het, is dat hy homself uitdruk met behulp van teologiese kategorieë wat, kultuur-antropologies gesien, anakronisties en Eurosentries is. In die lig van wat ek vroeër in die artikel gesê het, behoort Matteus se "eskatologie" myns insiens eerder verklaar te word in terme van 'n tydsbegrip waarin ervaarde tyd in verband gebring word met ver-beelde tyd. En om dit te doen, behoort die kontemporêre tekste wat met Matteus se eskatologie verband hou, nie buite rekening gelaat te word nie.

Dit is spesifiek die "messias-apokalips" in 2 Barug 53-74 en die Septuagint van Daniël 7:14 wat as Matteus se "intertekste" ten opsigte van "eskatologie" gesien kan word. In 2 Barug, die eerste "interteks", word die geskiedenis van Israel, soos in Matteus se genealogiese messiaanse register (Matt 1:1-17), opgedeel in drie tydperke van veertien seisoene elk. Die tweede "interteks", Daniël 7, het ooreenkomste met Matteus se beskrywing van Jesus se "finale vertrek" en die "groot opdrag" aan die dissipels soos opgeteken in Matteus 28:16-20.

Al verwys Matteus nie na die opgestane Jesus deur middel van Christologiese titels nie (vgl Schaberg 1982:135 nota 33), argumenteer Jane Schaberg (1982) oortuigend dat die triadiese formule in Matt 28:16-20 na alle waarskynlikheid 'n verwysing is na die Septuagint van Daniël 7:14. ${ }^{60}$ Net soos Josefus (Ant 4.326) Moses se "finale vertrek" in terme van Daniël 7 geïnterpreteer het, het Matteus deur middel van sy redaksionele aanpassing van 'n tradisie die "vertrek" van Jesus en die "sendingopdrag" aan die dissipels laat begin en eindig met 'n "troon-teofanie opdrag" (Schaberg 1982:189). Hierdie siening word gebaseer op die teorie dat sommige NuweTestamentiese triadiese tekste, ${ }^{61}$ waarvan Matteus 28:19b een is, ontwikkel het uit 'n oorspronklik Israelitiese apokaliptiese triade ${ }^{62}$ (Schaberg 1982:45).

Myns insiens verwys Matteus se siening met betrekking tot tyd, naamlik dat die einde reeds begin het, na die koms van die Seun van die mens en na die opdrag aan en sending van die ekklēsia. Teen die agtergrond van die vraag na die regverdiging van die dood van martelaars, word Daniël 7

\footnotetext{
${ }^{60} \mathrm{Vgl} \mathrm{Davies} \mathrm{\&} \mathrm{Allison} \mathrm{([1997]} \mathrm{2004:682-684);} \mathrm{Luomanen} \mathrm{(1998:194-260);} \mathrm{LaGrand} \mathrm{([1995]}$ 1999:236-238); Riches (2005:137-138).

${ }^{61}$ Byvoorbeeld, Markus 8:38; 13:32; Matteus 25:31-43; 13:36-43; Lukas 12:8-9; 1 Tessalonisense 4:13-18; 2 Tessalonisense 1:5-10; Openbaring 1:4-7; 5:6-7; 11:15-18 (vgl Schaberg 1982:286).

${ }^{62}$ Waarskynlik beïnvloed deur "formatiewe" Christelike denke met betrekking tot die drie-eenheid van die Vader, Seun en Heilige Gees, het Matteus die verwysings na die "Oue van Dae", "Seun

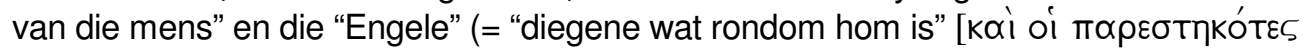

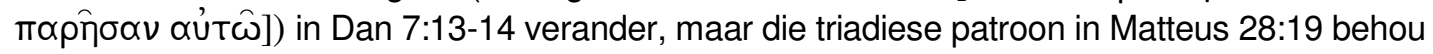
(vgl Schaberg 1982:45).
} 
geïnterpreteer as 'n belydenis van geloof dat die geregverdigde martelaar die dood oorwin. Hierdie opstandingsgeloof word in Daniël uitgebeeld in terme van 'n ou mitologiese gedagte van 'n oordrag van mag vanaf een godheid na 'n ander (vgl Schaberg 1982:187 ev). Matteus 28:19 v word dan verstaan as 'n midrash-tipe apokaliptiese verwysing met verbatim ooreenstemming met Daniël [LXX] 7:13-14:

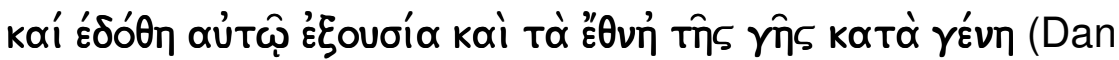
7:13-14).

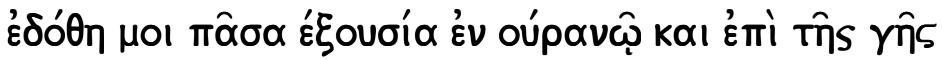

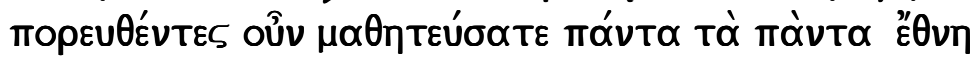
(Matt 28:18-20).

Beide passasies in Daniël 7:13-14 en Matteus 28:18-20 verwys dus na 'n eskatologiese gebeure, naamlik die begin van die einde wat die aanbreek van die "finale koninkryk" is (Schaberg 1982:115).

Dit is nie duidelik uit Daniël 7 of die periode van die "bose diere", wie se lewens volgens vers 12 verleng is, verby sal wees wanneer die gesag

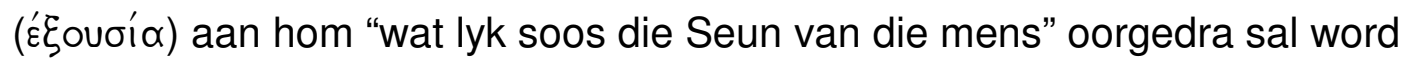
nadat dit van die vervolgers weggeneem is nie en of almal, volgens vers 14 , hom onmiddellik sal dien nie. ${ }^{63}$ Met ander woorde, selfs in Daniël 7 word die finale oomblik van regverdiging - uitgedruk in terme van ver-beelde simboliek en tyd - nie gesien as iets wat volkome "ervaar" sal word nie. Wat wel duidelik is, is dat hierdie "finale tyd" uitgeskuif word na 'n tyd en plek (die koninkryk) waar God alleen beheer uitoefen. Dit is 'n aspek in die Daniël-apokalips wat ooreenkom met die uitspraak in Matteus dat die aanvang van hierdie tyd deur niemand anders as God "die Vader" (Matt 24:36) geken word nie. Ook in Matteus 28:16-20 word die finale paroesie van die regverdiging van die Seun van die mens uitgeskuif na die afsluiting van die tyd - die "voltooiing van die

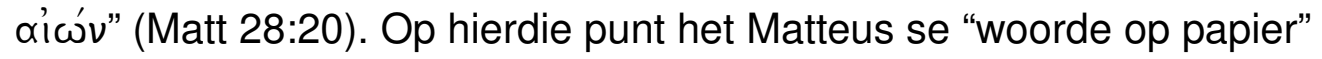
opgehou, want dit vorm die laaste in sy narratief, maar ook die begin van die "oop-einde". Vroeër in die essay (in voetnota 42) het ek wat die "betekenis" van die gebruik van die woord o'íw betref, na Philo Judaeus (De mutatione

\footnotetext{
${ }^{63}$ Daniël 7:14 toon 'n ooreenkoms met Matteus 28:17. In hierdie laaste verwysing na die dissipels in die Matteusevangelie word ' $n$ "oop-einde" aangedui in die sin dat party dissipels die

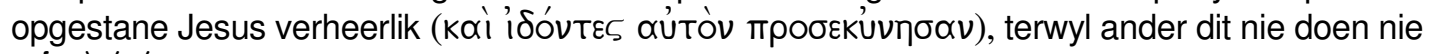

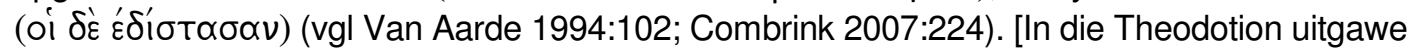

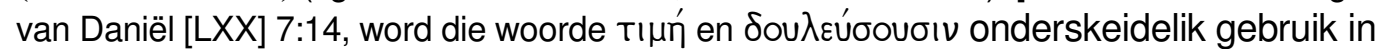

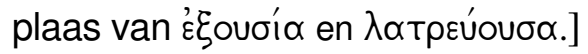


nominum 267) verwys wat sê dat hierdie soort "tyd" nie empiries "gemeet word aan die opkoms en ondergang van die son en die maan nie", maar dat dit betrekking het op "iets waarlik geheimsinnig, vreemd en nuut, buite die wêreld van sig en die (ander) sintuie".

Dit lyk of Matteus van oordeel was dat die (ver-beelde) gebeure wat beskryf word as die "sien van die Seun van die mens wat aan die regterhand van God sit", onmiddellik met die insident begin wat in Matteus 27:51b-53 berig word (vgl Gundry 1982:545).${ }^{64}$ Inderdaad vorm die verwysing na die

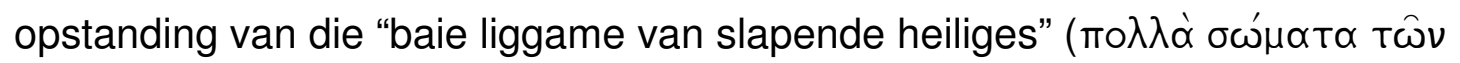

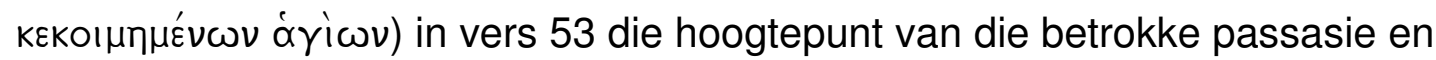
verse 51-54 vorm op hulle beurt weer die klimaks van die hele hoofstuk 27 (vgl Witherup 1987:578).

Die Ou-Testamentiese agtergrond van die apokaliptiese beelde van Matteus 27 is reeds lankal deur eksegete herken en beskryf (vgl Kratz 1973; Riebl 1978). Sommige van hulle het probeer om te argumenteer dat die verwysing na die "opstanding van die heiliges" as vooruitskouing na Jesus se opstanding teen die agtergrond van die beskrywing van die dood van die

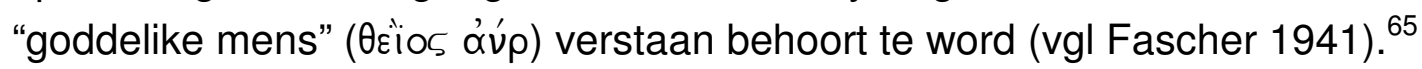
Dit blyk wel dat sekere tradisies (soos dié in 2 Makkabeërs 7; 1 Henog $51: 2 ; 66$ Esegiël 37:7, 12 en die Evangelie van Petrus 9:35-10:42) deel vorm van 'n gemeenskaplike agtergrond van waaruit Matteus stof gevind het om die gedeelte in 27:52-53 te komponeer (vgl Crossan 1988:392-393). ${ }^{67}$ In Esegiël 37:7 en 12 - net soos in Matteus 27:51b-53 (vgl Senior 1974:321) - word

\footnotetext{
${ }^{64}$ Saldarini (1994:192) meen dat die ooreenstemming tussen die apokaliptiese beelde in Matteus 27:51 e v en Matteus 28:16 e v daaruit bestaan dat Jesus se oorwinning oor die dood uiteindelik openbaar word deur wonderbaarlike verskynsels (aardbewing en lig; 28:2-3) en 'n betrokkenheid van 'n "hemelse boodskapper". Jesus verskyn weer as die apokaliptiese heerser en as die Seun van God (28:16-20), soos Hy vroeër gesê het (Matt 24-25).

${ }^{65}$ Ander weer oordeel dat Matteus die motief van (soos in die Isis-Osiris mitologie) die "dood van die [kosmiese] godheid" in gedagte kon gehad het (vgl Kratz 1973) of miskien die mitologiese idee van 'n "afdaling na die hel om die heiliges te bevry" (vgl Crossan 1988).

${ }^{66}$ Hierdie gedeelte kom tans voor in 1 Henog 37-71, die boek wat gewoonlik Die gelykenisse van Henog genoem word.

${ }^{67} 2$ Makkabeërs 7 beklemtoon dat die martelaars herhaaldelik hulle opstandingsoorwinning ervaar het as 'n beloning vir die getrouheid wat na hulle dood gelei het. In 1 Henog 51:1-2 lees ons spesifiek: "In daardie dae sal Sheol al die deposito's wat ontvang is, teruggee en die Hel sal alles wat verskuldig is, teruggee. En God sal die regverdiges en die heiliges (onder die opgestane dooies) uitkies, want die dag van hulle uitverkiesing en redding het aangebreek" (my vertaling aan die hand van Crossan).
} 


\section{"Op die aarde net soos in die hemel"}

daar melding gemaak van 'n reeks aardbewings, die oopgaan van die grafte, en die opstanding van dié wat begrawe is. ${ }^{68}$

Alhoewel die beskrywing in Matteus gebaseer is op na-eksiliese konsepte, kry ons in Mattteus (soos ook in die res van die Nuwe Testament) 'n weergawe van 'n opstandingsgeloof wat nie meer met die konteks toe hierdie voorstelling ontstaan het, ooreenkom nie (kyk Van Aarde 1989:219233). Vir die volgelinge van Jesus na- $70 \mathrm{nC}$ het die apokaliptiese metaforiek ten opsigte van die opstanding verander, omdat hulle geglo het dat 'n nuwe era met Jesus begin het. Die goddelike oorwinning oor die bose en die vernuwing van die skepping word na die verre toekoms uitgeskuif. Volgens die Christelike ekklēsia word die oorwinning oor die dood (wat hulle geglo het deur die opstanding van Jesus Christus tot stand gebring is) gesien as reeds volbring, en terselfdertyd sien hulle dit as iets in die toekoms, as iets wat by die paroesie gaan gebeur. In Matteus se plotintrige vind die oorgang vanaf die Jesus-sending na die dissipels-sending plaas op die tydstip toe Jesus gekruisig en uit die dood opgewek is.

In twee aparte artikels wys Trilling (1969a, 1969b) daarop dat die Wende der Zeit op hierdie punt van die Matteusevangelie plaasvind (vgl Meier 1975:207). Trilling sê in die eerste artikel dat Matteus 27:51 e v in dié opsig merkwaardig is, naamlik dat nie net die tempel se voorhangsel by Jesus se dood skeur nie - wat, volgens Die lewens van die profete (Habakuk) 12:1112, die oordeel van God oor die tempelkultus aandui (Garland 1995:260) en dus die einde van die ou kultiese orde laat aanbreek. Jesus se dood veroorsaak ook aardbewings (apokaliptiese simboliek in terme van Sag 14:4) en die opstanding van die dooies (apokaliptiese simboliek in terme van Eseg 37:13-14 en 1 Henog 51:1-2). Volgens David Sim (1996:104) kom hierdie uitsprake neer op "eskatologiese weë-uitroepe - in Afrikaans deesdae vertaal as "ellende-uitroepe". Die verwysing na 'n aardbewing is een van hierdie apokaliptiese elemente wat heenwys op die begin van die einde en die herordening van die wêreld (Trilling 1969a:195; Allison 1982:80-103). Sulke "kosmiese tekens" dien as die voorspel tot die koms van die Seun van die mens (Sim 1996:104). Trilling maak dieselfde punt in sy tweede artikel wanneer hy sê dat, in die konteks van Matteus 27:51 e v, hierdie verse gelees behoort te word as 'n aankondiging dat die dood van Jesus die begin van die

\footnotetext{
${ }^{68}$ Matteus was óf onbewus van, óf nie bekommerd oor die lomp voegwoord tussen verse 52 en 53 in Matteus 27 nie. Volgens Crossan (1988:392) was Matteus alleen daarin geïntereseerd om die "opstanding van die heiliges" aan te kondig en volgens die evangelis kan dit alleen gebeur ná Jesus se opstanding. Wat dus hier op die spel is, is die geloof van die volgelinge van Jesus (ingebed in 'n Israelse konteks en tradisie) in die gemeenskaplike opstanding. In die Evangelie van Petrus vind ons 'n beskrywing van 'n "begeleide" (escorted) en 'n "gesamentlike" (communal) opstanding.
} 
nuwe aeon inlui en dat dit op 'n verandering neerkom wat die hele kosmos raak. Tegelykertyd skep hierdie verandering op dramatiese wyse die verwagting in die narratief dat Jesus uit die dood opgewek sal word. Wat aangekondig word, is die tot niet gaan van die "ou tyd" en die aanbreek van die "nuwe tyd" (Trilling 1969b:221 e v; vgl Waetjen 1976:248). ${ }^{69}$

In Matteus se narratief funksioneer die gebruik van "intertekste" uit die leefwêreld van die Hebreeuse Bybel as rigtingwyser deur die verteller, om die verhaal in terme van die vertellers se perspektief (narrator's point of view) te lees. So gesien, volgens Graham Stanton (1992:348), funksioneer die inleidende formule van die vervullingsitate as die "asides of die evangelist" 'n perspektief wat nie in die mond van Jesus of van die ander karakters gelê word nie. As "bewyse" ontleen aan "Moses en die profete" vervul die vervullingsaanhalings as 'n "kommentariërende" rol waardeur die verteller in die verhaal 'n kontinuïteit en analogie tussen die voor-Pase Jesus-sending en die na-Pase dissipels-sending skep. Die kontinuïteit en analogie bestaan daaruit dat Jesus as God-met-ons op albei hierdie tydsvlakke - voor- en naPase - teenwoordig gemaak word. ${ }^{70}$ Jesus word as God-met-ons onder andere aan die begin (Matt 1:23) en aan die einde (Matt 28:20) van die narratief aangekondig.

So gesien - deur terug te keer na die beeld wat vroeër in die artikel gebruik is, naamlik die "draai van die gety" - kan die berig oor Jesus se genealogiese rekord as die Messias van Israel, wat aan die begin van Matteus se narratief berig word, reeds as eerste aanduiding van die eskatologiese wending van die "gety" in Israel se geskiedenis geïnterpreteer word (vgl Waetjen 1976:46-53). Ook die "messias-apokalips" in 2 Barug 53-74 verdeel die geskiedenis van Israel in drie tydvakke van veertien seisoene elk. Hierdie apokalipties-eskatologiese simboliek, soos reeds genoem, kom

\footnotetext{
${ }^{69}$ Meier (1975:207; 1976:30-35) meen ook dat die kruisiging en die opstanding van Jesus die Wende der Zeit inlui. Hy is egter van mening dat daar 'n radikale onderskeid bestaan tussen die "ou tyd" en die "nuwe tyd". Hy stel die "ou tyd" gelyk aan die "tyd van die Ou Testament" en dus met die pleidooi om "Moses en die profete" te gehoorsaam - die sogenaamde "tyd van partikularisme". Meier stel die "nuwe tyd" gelyk met die periode van "universalisme" wat met die dood en opstanding van Jesus begin het en waarna daar in die "ou tyd" uitgesien was (vgl o a tekste soos Matt 8:5-13 en 15:21-28). Meier baseer sy argument hoofsaaklik op die

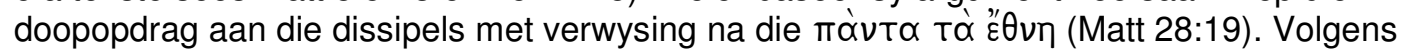
hom vervang die doop die besnyding, wat die "ou tyd" gesimboliseer het. Net soos partikularisme met universalisme vervang word, verval die noodsaaklikheid om aan die Mosaïese wette gehoorsaam te wees, volgens Meier, weg met Jesus se dood en opstanding.

${ }^{70}$ Volgens Senior (1976:672 v) gebruik Matteus die "Ou Testament" (Hebreeuse Bybel) om 'n kontinuïteit en analogie tussen sy Jesusbeeld en sy beeld van die ekklēsia daar te stel. Waetjen (1976:248) oordeel dat die dood van Jesus in Matteus ook die dood van Israel beteken en dat die beloftes van die Ou Testament daarom tegelykertyd vervul en gekanselleer is (vgl Waetjen 1976:244).
} 


\section{"Op die aarde net soos in die hemel"}

ooreen met die struktuur van Matteus se genealogiese register van Jesus as Israel se messias. ${ }^{71}$ In Matteus 1:17 "merk" beide die periodes van dié van Dawid en dié van die Babiloniese ballingskap die einde van 'n vorige tydvak en die aanvang van die daaropvolgende tydvak in Israel se geskiedenis. Albei hierdie oorgange hou verband met die "daar-wees" of die "vernietig-wees" van die Jerusalemse tempel. Albei tydvakke is op so 'n wyse gekonstrueer dat hulle uit veertien generasies saamgestel is. Die derde tydvak - wat verwys na die aanvang van die "tweede Tempelperiode" - eindig met die "ongelukkige" getal dertien. Op hierdie punt in sy "apokalipties-eskatologiese" beskrywing van Israel se geskiedenis, verwys Matteus na die geboorte van ó 'Inooûs ó

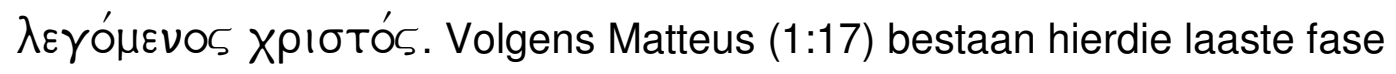
egter uit veertien generasies. In terme van die periodes van die vorige twee tydvakke in Israel se geskiedenis kan 'n mens verwag dat die "messiaanse periode", soos beide dié van Dawid en dié van die Babiloniese ballingskap, verband hou met die einde van 'n periode wat eindig met die vernietiging van die tempel en die begin van 'n nuwe "tempelperiode". Die veertiende generasie word in Matteus se genealogiese register egter nie met inhoud gevul nie.

Vanuit Wolfgang Iser (2006:64) se resepsie-estetiese interpretasie scenario, vorm hierdie "ongenoemde" generasie 'n "gaping" (Leerstelle) wat deur die eksegeet self met behulp van interne inligting vanuit die narratief self en eksterne inligting vanuit "intertekste" gevul moet word. Hierdie oorgang van die dertiende tydvak na die "ongenoemde" veertiende tydvak verteenwoordig die "eskatologiese draai van die gety". Die dertiende tydvak sentreer rondom die hoogbloei van tempelkorrupsie. Hierdie tydvak loop uit op die ervaring van die uiteindelike vernietiging van die Jerusalemse tempelkultus te midde van kosmiese katastrofes. Klaarblyklik fokus die veertiende tydvak op die konstruksie van 'n tempel wat nie deur mensehande gebou is nie. Die martelaarsdood van die regverdige Jesus - 'n dood wat Matteus in die konteks van ervaarde tyd as die gevolg van buitengewone tempelkorrupsie beleef - word geprojekteer na die konteks van ver-beelde tyd wat beskryf word in terme van die "sien van die koms van die Seun van die mens".

\footnotetext{
${ }^{71}$ Waetjen (1976:63 nota 9) meen dat hierdie raakpunt tussen 2 Barug en Matteus die eerste keer in 1841-44 in Hoffmann se werk voorkom en dat dit later oorgeneem is deur T Zahn en $\mathrm{K}$ Stendahl. Matteus se apokaliptiese uitbeelding van Israel se geskiedenis wat 'n klimaks in die messiaanse periode bereik, het 'n duidelike ooreenkoms met die uitbeelding in die "messiasapokalips" in 2 Barug 53-54. In laasgenoemde vind ons ook drie tydvakke van veertien periodes - elk word uitgebeeld in terme van die reënseisoen as "proseduretyd" (kyk Malina 1989:1-31). In beide Matteus en 2 Barug word die teenwoordigheid of die afwesigheid van die tempel in Jerusalem gesien as 'n aanduiding van goeie en slegte periodes in die geskiedenis van Israel. Die messiaanse ryk is die grand finale.
} 
Matteus kyk dus terug na die vernietiging van die Jerusalemse tempel in $70 \mathrm{nC}$ en beskryf sowel die kruisiging van Israel se messias as sy visie op die koms van die Seun van die mens vanuit hierdie terugskoue. Hierdie perspektief op Israel se geskiedenis bring Matteus by spesifieke redaksionele aanpassings van die tradisies wat hy ontvang het met betrekking tot die kruisiging en die opstanding van Jesus. Die evangelis beskou albei gebeure as vooruitgesien en dit bepaal sy redaksionele komposisie van hoofstuk 27:45-53 wat in apokalipties-eskatologiese terme geskryf is. Vanuit Matteus se eie ervaring van die ecclesia pressa - teen die agtergrond van die breuk met die Sinagoge - gee hy as 't ware sy lesers oor in die hande van God wat

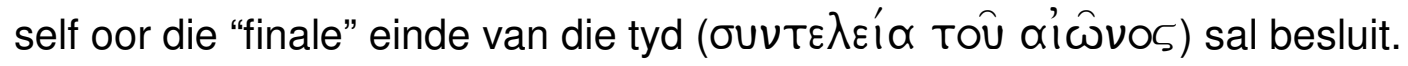
Dit lyk asof Matteus se bedoeling hiermee was dat die "verdrukte kerk" wat

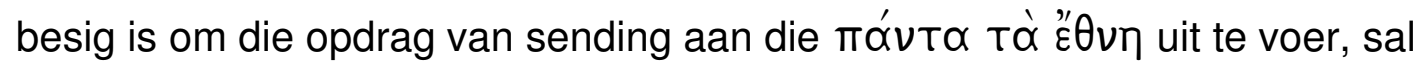
ervaar dat Jesus God-met-ons is, want die volgelinge van Jesus het die koms van die Seun van die mens gesien.

\section{Literatuurverwysings}

Allison, D C 1982. The end of the ages has come: An early interpretation of the passion and resurrection of Jesus. Philadelphia, PA: Fortress.

Aristotoles, Physica, edited by W D Ross [1950] 1966. Aristotelis physica, 1st ed corr. Oxford: Clarendon.

Barr, J 1961. Semantics of Biblical language. Oxford: Oxford University Press.

Becker, J 2007. Die Auferstehung Jesu Christi nach dem Neuen Testament: Ostererfahrung und Osterverständnis im Urchristentum. Tübingen: Mohr Siebeck.

Boman, T 1954. Das hebraïsche Denken im Vergeleich mit dem Griechischen. Göttingen: Vandenhoeck \& Ruprecht.

Borg, M J 1994. A temperate case for a non-eschatological Jesus, in Borg, M J, Jesus in contemporary scholarship, 47-68. Valley Forge, PA: Trinity Press International.

Borg, M J 1994b. Jesus and eschatology: Current reflections, in Borg, M J, Jesus in contemporary scholarship, 69-96. Valley Forge, PA: Trinity Press International.

Bornkamm, G [1956] 1961. Enderwartung und Auslegung im Matthäus-evangelium, in Bornkamm, G, Barth, G \& Held, H J, Überlieferung und Auslegung im Matthäusevangelium, 13-47. 2. Auflage. Neukirchen: Neukirchener Verlag. [Originally published in the 1956 Festschrift for C Dodd, The background of the New Testament and its eschatology, Cambridge: Cambridge University Press.]

Bourdieu, P 1963. The attitude of the Algerian peasant toward time, in Pitt-Rivers, J (ed) 1963, Mediterranean countrymen: Essays in the social anthropology of the Mediterranean, 55-72. Paris: Mouton. 
Butcher, S H [1894] 1951. Aristotle's theory of poetry and fine art, with critical text and translation of The Poetics. With a prefatory essay, Aristotelian literary criticism by J Gassner, 4th edition. New York: Dover.

Carter, W 2000. Matthew and the margins: A socio-political and religious reading. Sheffield: Sheffield Academic Press. (JSNT Suppl Series 204.)

Charlesworth, J H (ed) 1983. The Old Testament Pseudepigrapha, Vol 1: Apocalyptic literature and Testaments. London: Darton, Longman \& Todd.

Charlesworth, J H (ed) 1985. The Old Testament Pseudepigrapha, Vol 2: Expansions of the "Old Testament" and legends, wisdom and philosophical literature, prayers, psalms, and odes, fragments of lost Judeo-Hellenistic works. Garden City, NY: Doubleday.

Charlesworth , J H 1985. Introduction for the general reader, in Charlesworth 1985:xxi-xxxiv.

Cohen, J D 1992. The place of the rabbi in Jewish society of the second century, in Levine, L I (ed), The Galilee in late antiquity, 157-173. New York: Jewish Theological Seminary.

Collins, J J [1984] 1998. The apocalyptic genre, in Collins, J J, The apocalyptic imagination: An introduction to Jewish apocalyptic literature, 1-42, 2nd ed. Grand Rapids, MI: Eerdmans. (The Biblical Resource Series.)

Combrink, H J B 2007. Die Evangelie volgens Matteus: Wellington: Lux Verbi. (Skrifuitleg vir Bybelstudie en Gemeente.)

Cope, O L 1989. "To the close of the age": The role of apocalyptic thought in the Gospel of Matthew, in Marcus, J \& Soards, M L (eds), Apocalyptic and the New Testament: Essays in Honour of J Louis Martyn, 113-124. Sheffield: Sheffield Academic Press. (JSNTSS 24.)

Cullmann, O [1946] 1971. Christ and time: The primitive Christian conception of time and history, tr by F V Filson. London: SCM.

Cullmann, $\mathrm{O}$ 1956. The proleptic deliverance of the body according to the New Testament, in Higgins, A J B (ed), The early church. London: SCM.

Crossan, J D 1988. The cross that spoke: The origins of the Passion narrative. San Francisco, CA: Harper \& Row.

Crossan, J D 1997. Jesus and the kingdom: Itinerants and householders in earliest Christianity, in Borg, M J (ed), Jesus at 2000, 21-53. Boulder, CO : Westview. (A division of HarperCollins Publishers.)

Crossan, J D 1998. The birth of Christianity: Discovering what happened in the years immediately after the execution of Jesus. San Francisco, CA: HarperSanFrancisco.

Davies, W D \& Allison, D C [1997] 2004. A critical and exegetical commentary on the Gospel according to saint Matthew, Vol III. A Continuum Imprint. London: T \& T Clark;

Duling D C 1995a. The Matthean brotherhood and marginal scribal leadership, in Esler, P F (ed), Modelling early Christianity: Social-scientific studies of the New Testament in its context, 159-182. London: Routledge.

Duling, D C 1993. Matthew and marginality, in Lovering, E H (ed), Society of Biblical Literature 1993 Seminar Papers 32, 642-671. Atlanta, GA: Scholars Press. [Revised and reprinted in Duling, D C 1995b. HTS 51(1), 1-30.]

Duling, D C 2002. Matthew as marginal scribe in an advanced agrarian society. HTS 58(2), 520-575. 
Dunn, J D G [1977] 2006. Unity and diversity in the New Testament: An inquiry into the character of earliest Christianity, 3rd edition. London: SCM.

Fascher, E 1941. Anastasis-Resurrectio-Auferstehung: Eine programmatische Studie zum Thema "Sprache und Offenbarung. ZNW 40, 166-229.

Funk, R W \& The Jesus Seminar 1999. The gospel of Jesus according to the Jesus Seminar. Santa Rosa, CA: Polebridge.

Garland, D E [1993] 1995. Reading Matthew: A literary and theological commentary on the First Gospel. New York: CrossroadGosden, C 1994. Social being and time. Oxford: Blackwell.

Gundry, R H 1982. Matthew: A commentary on its literary and theological art. Grand Rapids, MI: Eerdmans.

Hadfield, P 1959. Matthew the apocalyptic editor. LondQHolbRev 28, 128-132.

Hagner, D A 1985. Apocalyptic motifs in the Gospel of Matthew: Continuity and discontinuity. Horizons in Biblical Theology 7, 53-82.

Hagner, D A 1994. Matthew's eschatology, in Schmidt, T E \& Silva, M (eds), To tell the mystery: Essays on New Testament eschatology in honor of Robert G Gundry, 49-71. Sheffield: JSOT Press. (JSNT Supplement Series 100.) [Reprinted in SBLSP 35 (1996), 163-181.]

Hahn, F 1988. Die eschatologische Rede Matthäus 24 und 25, in Schenke, L (Hrsg), Studien zum Matthäusevangelium: Festschrift für Wilhelm Pesch, 109-126. Stuttgart: Katholisches Bibelwerk. (SBS.)

Hare, D R A 1985. The Lives of the Prophets, in Charlesworth 1985:379-400.

Hare, D R A 1993. Matthew. Louisville, KY: John Knox. (Interpretation: A Bible Commentary for Teaching and Preaching.)

Harrington, D J 1985. Pseudo-Philo, in Charlesworth 1985:297-377.

Hengel, M 1969. Judentum und Hellenismus: Studien zu ihrer Begegnung unter besonderer Berucksichtigung Palastinas bis zur Mitte des 2.Jh. v.Chr. Tübingen: Mohr. (WUNT 10.)

Hengel, M 1974. Judaism and Hellenism: Studies in their encounter in Palestine during the early Hellenistic period. London: SCM.

Hengel, M 1995. "Sit at my right hand!", in Studies in early Christology, 119226. Edinburgh: T \& T Clark.

Hertig, P 1998. Matthew's narrative use of Galilee in the multicultural and missiological journeys of Jesus. Lewiston, NY: Edwin Mellen. (Mellen Biblical Press Series 46.)

Horsley, R A 1987. Jesus and the spiral of violence: Popular Jewish resistance in Roman Palestine. San Francisco: Harper \& Row.

Horsley, R A 1991. Q and Jesus: Assumptions, approaches and analyses. Semeia 55, 175-209.

Horsley, R A 1996. Archeology, history, and society in Galilee: The social context of Jesus and the rabbis. Valley Forge, PA: Trinity Press International.

Isaac, E 1983. 1 (Ethiopic Apocalypse of) Enoch, in Charlesworth 1983:5-89.

Iser, W 2006, Reception theory: Iser, in Iser, W, How to do theory, 57-69. Malden, MA: Blackwell. (How to Study Literature.)

Käsemann, E 1954-55. Sätze heiligen Rechtes im Neuen Testament. NTS 1, 248260.

Käsemann, E 1960. Die Anfänge christlicher Theologie. ZThK 57, 162-185. 
Käsemann, E [1960] 1969. The beginnings of Christian theology, in New Testament questions of today, tr by W J Montague, 82-107. London: SCM. (The New Testament Library.)

Kingsbury, J D 1973. The structure of Matthew's gospel and his concept of salvationhistory. CBQ 35, 451-474.

Knight, G A F 1953. A Biblical approach to the doctrine of the Trinity. Edinburgh: Oliver and Boyd.

Kingsbury, J D 1977. Matthew. Philadelphia, PA: Fortress.

Klijn, A F J 1983. 2 (Syriac Apocalypse of) Baruch, in Charlesworth 1983:615-652.

Kloppenborg, J S 2000. Excavating Q: The history and setting of the Sayings Gospel. Minneapolis, MN: Fortress.

Kraft, R A \& Nickelsburg, G W E 1986. Early Judaism and its modern interpreters. Atlanta, GA: Scholars Press.

Kratz, R 1973. Auferweckung als Befreiung: Eine Stunde zur Passions- und Auferstehungstheologie des Matthäus. Stuttgart: Katholisches Bibelwerk. (SBS 65.)

Kreuzer, Jo 2005a. Zeit- und Geschichtsbild, in Zangenberg, J (Hrsg), Neues

Testament und Antike Kultur, Band 3: Weltauffassung - Kult - Ethos, 110-

114. Neukirchen-Vluyn: Neukirchener Verlag.

Kreuzer, J 2005b. Von der erlebten zur gezählten Zeit: Die Anfänge der Zeitphilosophie in der Antike, in Kreuzer, J \& Mohr, G (Hrsg), Die Realität der Zeit, 1-49. München: Kaiser.

Lauer, R H 1981. Temporal man: The meaning and uses of social time. New York: Praeger.

LaGrand, J [1995] 1999. The earliest Christian mission to "all nations" in the light of Matthew's gospel. Grand Rapids, MI: Eerdmans.

Levine, L I 1992. The sages and the synagogue in late antiquity, in Levine, L E (ed), The Galilee in late antiquity, 201-222. New York: Jewish Theological Seminary.

Louw, J P 1982. Semantics of New Testament Greek. Philadelphia, PA: Fortress. (THE SBL Semeia Studies.)

Luomanen, P 1998. Entering the kingdom of heaven: A study on the structure of Matthew's view of salvation. Tübingen: Mohr Siebeck. (WUNT II/101.)

Luz, U [1985] 1989. Matthew 1-7: A commentary. Minneapolis, MN: Fortress.

Luz, U 2005. Matthew 21-28: A commentary. Minneapolis, MN: Fortress. (Hermeneia.)

Malina, B J 1989. Christ and time: Swiss or Mediterranean. CBQ 51, 1-31. [Reprinted in Malina, B J 1996. The social world of Jesus and the Gospels, 179-214. London: Routledge.]

Malina, B J 1991. Is there a circum-Mediterranean person? Looking for stereotypes. BTB 22(2), 66-87.

Malina, B J 1993. Windows on the world of Jesus: Time travel to ancient Judea. Louisville, KY: Westminster John Knox.

Malina, B J 2001. The social gospel of Jesus: The kingdom of God in Mediterranean perspective. Minneapolis, MN: Fortress.

Marxsen, W 1959. Der Evangelist Markus: Studien zur Redaktionsgeschichte des Evangeliums. Göttingen: Vandenhoeck \& Ruprecht. 
Meier, J P 1975. Salvation-history in Matthew: In search of a starting point. CBQ 37, 203-15.

Meier, J P 1976. Law and history in Matthew's gospel: A redactional study of Mt. 5:17-48. Rome: Biblical Institute Press. (Ana.Bib. 71.)

Miller, R J (ed) 2001. The apocalyptic Jesus: A debate. Santa Rosa, CA: Polebridge. Murphy, F J 1994. Apocalypses and apocalypticism: The state of the question. Currents in Research: Biblical Studies 2, 147-180.

Neyrey, J H \& Rowe, E [2008]. "Telling time" in the Fourth Gospel. HTS 64(1), 291320.

Nickelsburg, G [1972] 2006. Resurrection, immortality, and eternal life in Intertestamental Judaism and early Christianity. Expanded edition. Cambridge: MA: Harvard University Press. (Harvard Theological Studies, Harvard Divinity School.)

Orton, D E 1989. The understanding scribe: Matthew and the apocalyptic ideal. Sheffield: Sheffield Academic Press. (JSNT Sup 25.)

Overman, J A 1990. Matthew's gospel and formative Judaism: The social world of the Matthean community. Minneapolis, MN: Fortress.

Patterson, S J 1992. The end of eschatology? Ongepubliseerde studiemateriaal vir Westar Institute Program, Los Robles Lodge, Santa Rosa, California, 27 February-1 March 1993.

Repschinski, B 2000. The controversy stories in the Gospel of Matthew: Their redaction, form and relevance for the relationship between the Matthean community and formative Judaism. Göttingen: Vandenhoeck \& Ruprecht. Forschungen zur Religion und Literatur des Alten Testaments 189.)

Riches, J 1997. Matthew. Sheffield: Sheffield Academic Press. (New Testament Guides.)

Riches, J 2005. Matthew's missionary strategy in colonial perspective, in Riches, J \& Sim, D C (eds), The Gospel of Matthew in its Roman imperial context, 128142. A Continuum Imprint. London: T \& T Clark. (JSNTS 276.)

Riebl, M 1978. Auferstehung Jesu in der Stunde seines Todes? Zur Botschaft von Mt 27, 51b-53. Stuttgart: Katholisches Bibelwerk. (SSB 8.)

Robinson, J M 2007. Jesus: According to the earliest witness. Minneapolis, MN: Fortress.

Saldarini, A J 1991. The Gospel of Matthew and Jewish-Christian conflict, in Balch, D $\mathrm{L}$ (ed), Social history of the Matthean community: Cross-disciplinary approaches, 38-61. Minneapolis, MN: Fortress.

Saldarini, A J 1994. Matthew's Christian-Jewish community. Chicago, II: University of Chicago Press.

Saler, B 1977. Supernatural as a Western category. Ethos 5, 31-53.

Sand, A 1972-3. Zur Frage nach dem "Sitz in Leben" der apokalyptischen Texte des neuen Testaments. NTS 18, 167-177.

Sanders, J T 1975. Ethics in the New Testament: Change and development. Philadelphia, PA: Fortress.

Schaberg, J 1982. The Father, the Son and the Holy Spirit. Chico, CA: Scholars Press. (SBLDS 61.)

Schlatter, A [1933] 1963. Der Evangelist des Matthäus. Seine Sprache, seine Ziel, Seine Selbbeständigkeit: Ein Kommentar zum ersten Evangelium. 6. Auflage. Stuttgart: Calwer Verlag. 
Schmithals, W 1973. Die Apokalyptik: Einführung und Deutung. Göttingen: Vandenhoeck. (Sammlung Vandenhoeck.)

Schmithals, W 1975. Jesus und die Apokalyptik, in Strecker, G (Hrsg), Jesus Christus in Historie und Theologie: Festschrift für Hans Conzelmann, 59-85. Tübingen: Mohr.

Schmithals, W 1994. Theologiegeschichte des Urchristentums: Eine problemgeschichtliche Darstellung. Stuttgart: Kohlhammer.

Schotroff, $L$ 2006. The parables of Jesus, tr by L M Maloney. Minneapolis, MN: Fortress.

Senior, D P 1974. The death of Jesus and the resurrection of the holy ones (Mt 27:51-53). CBQ 38, 312-329.

Senior D P 1976. The ministry of continuity: Matthew's gospel and the interpretation of history. BiTod 82, 670-676.

Senior's, D P 2001. Directions in Matthean Studies, in Aune, D E (ed), The Gospel of Matthew in current study: Studies in memory of William G Thompson, 5-21. Grand Rapids, MI: Eerdmans.

Sim 1996. Apocalyptic eschatology in the Gospel of Matthew. Cambridge: Cambridge University Press. (SNTS Monograph Series.)

Sim, D C 1998. The Gospel of Matthew and Christian Judaism: The history and social setting of the Matthean community. Edinburgh: T\& T Clark. (Studies of the New Testament and its World.)

Stanton, G N 1992. A Gospel for a New People: Studies in Matthew. Edinburgh: T \& T Clark.

Sterling, G E 2000. s v Philo. Dictionary of New Testament background, 789-793, edited by C A Evans \& S E Porter. Downers Grove, II: Inter-Varsity Press.

Stewart, R B (ed) 2006. The resurrection of Jesus: John Dominic Crossan and N T Wright in dialogue. Minneapolis, MN: Fortress.

Strecker, G [1966] 1971. Der Weg der Gerechtigkeit: Untersuchung zur Theologie des Matthäus. 2. Auflage. Göttingen: Vandenhoeck \& Ruprecht.

Theissen, G. [1974] 1983. The miracle stories of the early Christian tradition, tr by $\mathrm{F}$ McDonagh, ed by J Riches. Edinburgh:T. \& T. Clark.

Theissen, G [1999] 1999. A theory of primitive Christian religion, tr by J Bowden. London: SCM.

Treese, $R L$ 1958. The eschatology of the compiler of the Gospel according to Saint Matthew. PhD dissertation, Boston University Graduate School.

Trilling, W 1969a. Der Tod Jesu: Ende der alten Weltzeit (Mk 15,33-41), in Trilling, W (Hrsg), Christusverkündigung in den synoptischen Evangelien: Beispiele gattungsgemässer Auslegung, 191-211. München: Kösel.

Trilling, W 1969b. Die Auferstehung Jesu: Anfang der neuen Weltzeit (Mt 28:1-8), in Trilling, W (Hrsg), Christusverkündigung in den synoptischen Evangelien: Beispiele gattungsgemässer Auslegung, 212-243. München: Kösel.

Van Aarde, A G 1989. Hgerthe apo tōn nekrōn (Mt 28:7): A textual evidence on the separation of Judaism and Christianity. Neotestamentica 23, 219-233.

Van Aarde, A G 1994. God-with-us: The dominant perspective in Matthew's story, and other essays. Pretoria: University of Pretoria. (HTS Suppl 5.)

Van Aarde, A G 1999. The historicity of the circle of the Twelve: All roads lead to Jerusalem. HTS 55(2\&3), 795-826. 
Van Aarde, A G 1998. Matthew 27:45-53 and the turning of the tide in Israel's history. BTB 28(1), 16-26. [Reprinted in HTS 1999, 55(2\&3), 671-692.]

Van Aarde, A G 2001a. Fatherless in Galilee: Jesus as child of God. Harrisburg, PA: Trinity Press International.

Van Aarde, A G 2001b. Millennialisme, eskatologie en apokaliptiek. HTS 57(3\&4), 1158-1178.

Van Aarde, A G 2002. Matthew and apocalypticism as the "mother of Christian theology": Ernst Käsemann revisited. HTS 58(1), 118-142.

Van Aarde, A G 2005. IHSOUS, the Davidic Messiah, as political saviour in Matthew's history, in Van der Watt, J G (ed), Salvation in the New Testament: Perspectives on soteriology, 7-32. Leiden: Brill. (Supplements to Novum Testamentum 121.)

Van Aarde, A G 2006. Genre en plot georiënteerde narratief-kritiese eksegese van Evangeliemateriaal: Inleiding tot narratiewe kritiek. HTS 62(2), 657-677.

Van Aarde, A G 2007. Jesus' mission to all of Israel emplotted in Matthew's story. Neotestamentica 41(2), 416-436.

Waetjen, H C 1976. The origin and destiny of humanness: An interpretation of the Gospel according to Matthew. San Rafael, CA: Crystal.

Walker, R 1967. Die Heilsgeschichte im ersten Evangelium. Göttingen: Vandenhoeck \& Ruprecht.

Walsh, R G 2001. Mapping myths of Biblical interpretation. Sheffield: Sheffield Academic Press. (Playing the Texts 4.)

Weren, W J C 1979. De broeders van de Mensenzoon: Mt 25, 31-46 als toegang tot de eschatologie van Matteüs. Amsterdam: Ton Bolland.

Wilder, A N 1966, Kerygma, eschatology and social ethics. Philadelphia, PA: Fortress. (Facet Books Social Ethics Series 12.)

Witherup, R D 1987. The death of Jesus and the rising of the saints: Matthew 27:5153 in context. SBLSP 26, 547-585.

Wright, N T 2003. The resurrection of the Son of God. Minneapolis, MN: Fortress. (Christian Origins and the Question of God, Vol 3.)

Wright, N T \& Crossan, J D 2006. The resurrection: Historical event or theological explanation? A dialogue, in Stewart, R B (ed), The resurrection of Jesus: John Dominic Crossan and N T Wright in dialogue, 16-47. Minneapolis, MN: Fortress.

Yueh-Han Yieh, J 2004. One teacher: Jesus' teaching role in Matthew's gospel report. Berlin: De Gruyter. (BZNW 124.) 